\title{
Andriake'de Ele Geçen Roma Dönemi Mortarları
}

\author{
Cüneyt ÖZ* (iD
}

\section{Öz}

Andriake, Antalya İli, Demre İlçesi’nde yer alan Myra antik kentinin liman yerleşimidir. Liman, günümüzde Kokarçay (Andriakos) olarak adlandırılan çayın denize döküldüğü Çayağzı mevkiinde kurulmuştur. Andriake limanındaki kazılar 2009 yılından bu yana geniş katılımlı bir ekip tarafından sürdürülmektedir. Şarap İşlikleri, 2015 Yılı İşlik Kazısı Atık Toprağı, Horrea Hadriani/Granarium, Sinagog, Horrea Hadriani/Granarium Önü ve Liman Yapılarındaki kazılarda ortaya çıkarılan 12 adet pişmiş toprak mortar bu çalışmanın konusunu oluşturmaktadır. Farklı dillerde birçok değişik isimle anılan mortarlar antikçağ mutfağının vazgeçilmez araç-gereçlerindendir. Mortarlar mutfakta ekmek, kek, yulaf lapası, püre, çorba ve peynir yapımı, çeşitli tahıl, bitki ve baharatları ezme/ögütme ve etlerin marinasyonunun yapılması gibi birçok alanda kullanılmıştır. Bunlar dışında kutsal törenlerde, kuru gıdaların ölçümünde, tıp ve kozmetikte, cam ve bazı metallerin ezilmesinde, boya yapımında, urne olarak ölü gömme ritüellerinde, mezar hediyesi, pithos ve amphora kapağı olarak birçok farklı alanda da kullanılmışlardır.

Andriake'de ele geçen Roma Dönemi’ne ait mortarlar ağız profillerine göre altı farklı tipte incelenmiştir. Bunlardan Tip 1 ve Tip 4 İtalyan mortarları olarak adlandırılmıştır. Tip 2'ye ait mortarın benzeri yoktur. Bu tipin Myra'da üretilen yerel bir tip olduğu düşünülmektedir. Tip 3 mortarının benzerine Suriye'de rastlansa da kökeni belirsizdir. Tip 5 ve Tip 6 örnekleri ise Suriye mortarları olarak bilinmektedir. Fakat bu iki tipin Suriye de mi? yoksa Myra da mi? üretildikleri konusu şu an için netlik kazanmamıştır. Tip 5'e ait mortarlardan ikisi üzerinde Grekçe yazıt yer alır. Bir örneğin üzerindeki yazıt iyi şans dileği belirtirken, diğerindeki muhtemelen atölye/üretici veya hediye edenin ismini veriyor olmalıdır. Çalışmada değerlendirilen mortarlar MÖ 1. yüzyılın sonu ile MS 6. yüzyıl arası gibi geniş bir tarih aralığına aittir. Andriake'de ele geçen mortarların oldukça farklı tipte çeşitlilik arz ettiği görülmektedir. Andriake mortarların incelendiği bu çalısma sonucunda kent ve bölge mortar tipolojisine ve seramik çalışmalarına yeni katkılar sunulmaktadır.

Anahtar Kelimeler: Myra (Likya), Andriake Limanı, Roma Dönemi, Mortar, Havan

\section{Roman Mortars Unearthed on Andriake}

\begin{abstract}
Andriake is the port settlement of the ancient city of Myra in Demre District of Antalya Province. The port was established in Çayağzı area, where the stream currently called Kokarçay (Andriakos) flows into the sea. Excavations in the Andriake port are being carried out by a large team since 2009. The subject of this study comprises 12 terracotta mortars unearthed in the excavations in the Wine Workshops, 2015 Workshop Excavation Soil, Horrea Hadriani/Granarium, Synagogue, Front of Horrea Hadriani/Granarium, and Harbor Buildings. Known by many different names in different languages, mortars are indispensable tools of kitchens of the archaic period. Mortars have been used in many areas in the kitchen, such as making bread, cake, porridge, puree, soup, and cheese, crushing/grinding various grains, herbs and spices, and marinating meats. Other than these, they have been used in many different areas, in sacred ceremonies, measurement of dry foods, medicine and cosmetics, crushing glass and certain metals, making paint, as urns in burial rituals, as grave gifts, as pithos and amphora covers.

Roman mortars unearthed from Andriake were analyzed in six different types according to their mouth profiles. Of these types, Type 1 and Type 4 were called Italian mortars. Type 2 mortar is unique. This mortar type is believed to be a local type manufactured in Myra. Although a type similar to Type 3 mortar was found in Syria, its origin is unknown. Type 5 and Type 6 mortars are known as Syrian mortars. But it is yet unclear whether these two types were manufactured in Syria or in Myra. There are inscriptions in Greek on two of the Type 5 mortars. While the inscription on one of the specimens was a good luck wish, the other one probably indicated the name of the factory/manufacturer or the gift giver. Mortars evaluated in the study belong to a wide date range, between the end of the 1st century $\mathrm{BC}$ and the 6th century $\mathrm{AD}$. It is seen that the mortars unearthed from Andriake have a wide range of different types. The results of this study, in which Andriake mortars were analyzed, provide new contributions to the provincial and regional mortar typology and ceramic works.
\end{abstract}

Keywords: Myra (Lycia), Andriake Port, Roman Period, Mortar/Mortarium, grinding bowl

\section{Giriş}

Myra'nın liman yerleşimi Andriake ${ }^{1}$ ana kentin güneybatısında, Andriakos (Kokarçay) Çayı'nın denize döküldüğü yerde kurulmuş olup günümüzde Antalya İli, Demre İlçesi’nde Çayağzı mevkiinde yer almaktadır (Harita 1). Prof. Dr. Nevzat Çevik başkanlığında, 2009 yılından bugüne, kalabalık bir ekip

\footnotetext{
* Dr. Öğr. Üyesi, Dicle Üniversitesi, cuneyt.oz@outlook.com

Makalenin Gönderim Tarihi: 17.04.2021; Makalenin Kabul Tarihi: 22.09.2021
}

doi: 10.52642 /susbed.918613

1 Andriake limanı antik kaynaklarda epineion (limanı/demirleme yeri) ve emporion (ticaret merkezi) olarak adlandırllır (Aygün, 2018, s. 5). 
tarafindan yapılan kazı çalışmalarının odak noktasını Andriake limanı oluşturmuştur². Andriake'de yer alan Horrea Hadriani/Granarium, Agora/Plakoma, Germanicus Meydanı, Liman Yapıları, Şarap İşlikleri, Sinagog, Doğu Hamam, Batı Hamam, Onurlandırma Anıtları, A Kilisesi, B Kilisesi, Güneydoğu Nekropolü gibi birçok alanda kazı çalsşması yürütülmüştür ${ }^{3}$. Ad1 geçen alanlarda yapılan kazı çalışmalarında çok sayıda buluntuyla (seramik, sikke, kandil, mimari parçalar vb.) karşılaşılmıştır. Bu çalısmalardan elde edilen veriler sonucunda Andriake limanının MÖ 4. yüzyıl sonundan MS 7. yüzyllın ortalarına kadar kesintisiz bir iskân gördüğü anlaşılmaktadır (Bulut \& Şengül, 2014, s. 86)4.

Çalış̧mada 12 adet pişmiş toprak mortar değerlendirilmektedir. En yoğun ele geçtikleri alan Şarap İşlikleri ve 2015 İşlik Kazısı Atık Toprağı (3)'dır. Bunu sırasıyla Horrea Hadriani/Granarium (2), Horrea Hadriani/Granarium Önü (2), Sinagog (1) ve Liman Yapıları (1) izlemektedir (Fotoğraf 1, 2). Andriake güney yerleşiminin merkezinde, Horrea Hadriani/Granarium'un kuzeyinde ve Sinagog'un batısında yer alan Şarap İşlikleri'nin kazısına 2012 yılında başlanmıştır. İşliklerin ilk yapım evresi bilinmemekle birlikte ikincil kullanımı için MS 4. yüzyıl tarihi önerilmektedir (Çevik vd., 2013, s. 93-94; Aygün, 2018, s. 202-203). Alandaki kazılarda yoğun olarak ele geçen seramiklerin tarihine (MS 1.-12. yüzyıl) bakıldığında, mekânın şarap işliği olarak kullanımından sonra seramik çöplüğüne dönüştürülmüş olduğu düşünülmektedir (Çevik vd., 2013, s. 93). Önceki kazı sezonunda (2015) farklı bir ekip tarafından yapılan Şarap İşlikleri kazısının atık toprağı işliklerin hemen kuzeyindeki alanda biriktirilmiştir. 2016 yılında N. Çevik başkanlığında bir ekip tarafindan atık toprağın alandan uzaklaştırılması için çalışma başlatılmış; bu çalışma neticesinde atık toprak içerisinden çok sayıda seramik, metal ve cam eser ile sikke buluntularıyla karşılaşılmıştır. Ele geçen buluntular Hellenistik Dönem'den Bizans Dönemi'ne kadar oldukça geniş bir tarih aralı̆̆ına aittir ${ }^{5}$. Kazı ve restorasyonu 2009 yllinda tamamlanan Sinagog, Horrea Hadriani/Granarium'un hemen kuzeybat1 köşesinde Şarap İşlikleri'nin ise doğusunda yer almaktadır. Bölgede ortaya çıkarılan ilk Sinagog olan bu yap1 MS 5.-6. yüzyıla tarihlendirilmektedir (Çevik vd., 2010a, s. 349) ${ }^{6}$. Kazılarda yapının zemininde MÖ 3. yüzyıl ile MS 7. yüzyıl arasına tarihlenen çok sayıda seramik (Özdilek, 2015; Özdilek, 2016; Özdilek, 2017; Özdilek, 2018; Öz, 2020) dolgu malzemesiyle karşılaşılmıştır. Andriake güney yerleşimin merkezinde Agora/Plakoma'nın batısında yer alan Horrea Hadriani/Granarium, İmparator Hadrianus Dönemi'nde inşa edilmiştir (Çevik vd., 2014, s. 236-237). Yapılan kazı çalışmalarında MS 2. yüzyılda inşa edilen yapinın 4. yüzyılda oldukça yoğun kullanıldığı, bu kullanımının 8. yüzyıla kadar da devam ettiği tespit edilmiştir7. Horrea Hadriani/Granarium'un müzeye dönüştürülme çalışmasında yapının önünde kazı ve temizlik çalışmaları yapılmıştır. Bu çalışmalarda küçük buluntular dışında yoğun bir şekilde farklı dönemlere ait seramikler ${ }^{8}$ ele geçmiştir. Liman yapıları dükkân, depo, tersane ve gemi barınaklarının yer aldığı kompleks yapılar topluluğudur. Kazıları 2009 ve 2010 yıllarında yapılmıştır. İlk olarak dükkanlar kazılmış, elde edilen verilere göre ilk kullanım evreleri MS 3. yüzyıl, son kullanım evreleri ise MS 6. yüzyıla tarihlenmektedir9.

\section{Mortarlar ve Kullanım Alanları (Genel Bilgiler)}

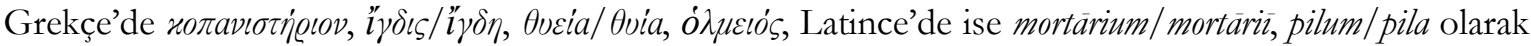
adlandırılan mortarlar eski çağda mutfakların vazgeçilmez kaplarından birisidir ${ }^{10}$. Vallerin ise bu kaplara

\footnotetext{
${ }^{2}$ Kazı çalışmalarından önce limanda yapılan yüzey araştırmalarının sonuçları için ayrıca bkz (Marksteiner, 2006, s. 41-46; Marksteiner, 2007, s. 98-101; Yener-Marksteiner, 2009, s. 105-107; Yener-Marksteiner, 2013, s. 225-232).

3 Andriake ile ilgili ayrıntılı bilgi için bkz (Akyürek, 2014; Aygün, 2018; Bulut \& Şengül, 2014; Çevik, 2010a; 2010b; Çevik, 2016; Çevik \& Bulut, 2010; Çevik \& Bulut, 2011; Çevik \& Bulut, 2014; Çevik \& Eshel, 2010; Çevik vd., 2010a; 2010b; Çevik vd., 2011; Çevik vd., 2012; Çevik vd., 2013; Çevik vd., 2014; Çevik vd., 2017; Çevik vd., 2018a; 2018b).

${ }^{4}$ Kazılarda ele geçen ve sayıları giderek artan MS 11. yüzyıla tarihlenen anonim follisler ile MS 12-13. yüzyıla tarihlenen seramik parçası bize Andriake'nin bu dönemlerde de yerleşim görmüş olabileceğini düşündürür (Bulut \& Şengül, 2014, s. 88).

5 Ayrıntılı bilgi için bkz (Çevik vd., 2017, s. 73-74, Fig. 11-14; Çevik vd., 2018b, s. 193-194); bu çalışmada ele geçen seramiklerin değerlendirmesi için bkz (Öz, 2020).

${ }^{6}$ Sinagog hakkında ayrıntılı bilgi için ayrıca bkz (Çevik \& Bulut, 2010, s. 46-47; Çevik, 2010b, Çevik vd., 2010a; 2010b).

${ }^{7}$ Sikkeler için bkz (Bulut \& Şengül, 2010; Bulut \& Şengül, 2014, s. 85); seramikler için bkz (Öz, 2020).

8 Özdilek, 2016; Geç Roma Seramikleri için ayrıca bkz (Öz 2020).

${ }^{9}$ Liman yapıları hakkında ayrıntılı bilgi için bkz (Çevik, 2010b; Çevik \& Bulut, 2010, s. 45-46; Çevik \& Bulut, 2011, s. 6-8; Aygün, 2018, s. 163-165); Liman yapılarındaki dükkanlarda ele geçen seramikler için bkz. (Özdilek, 2016; Öz, 2020).

${ }^{10}$ Mortarların isimlendirilmelerindeki ayrım için ayrıca bkz (Moritz, 1958, s. 22 vd.); Günümüzde kullanılan çeşitlerine havan denmektedir.
} 
pelves dendiğini öne sürmektedir (Vallerin, 1994; Mills, 2014, s. 26). Genelde pişmiş topraktan yapılmalarına rağmen taştan ${ }^{11}$ yapılan örnekleri de bolca bulunmaktadır ${ }^{12}$. Paleolitik Dönem'de mısır öğütmek/ezmek için kullanılan doğal kaya oyukları, sonrasında yerini taşınabilir mortarlara bırakmıştır (Moritz, 1958, s. 24 vd.). Neolitik Dönem'de de ęgi taşı olarak adlandırılan taş kaplar (Doğan, 2007, s. 64) aslında sonrasında bir tipe/şekle kavuşan mortarların öncüleri olmalıdır. Mortarların en erken örnekleri MÖ 8. yüzyılın sonlarında görülürken (Zukerman \& Ben-Shlomo, 2011, s. 90 vd.), 7. ve 6. yüzyıl içerisinde oldukça yaygin şekilde birçok bölgede (Levant, Fenike, Doğu Akdeniz, Ege, Kıbrıs, Mısır, Kuzey Suriye, Güney Anadolu kıyıları, Pannonia Bölgesi, Almanya, Galya ve Britanya gibi) kullanılmaya başlanmıştır (Lehmann, 1996, s. 388-389, Taf. 25, 26: 159-164; Lehmann, 1998, s. 15, 18, Fig. 6: 17-18; Waldbaum \& Magness, 1997, s. 3940; Bellelli \& Botto, 2002, s. 277 vd.; Villing, 2006; Zukerman \& Ben-Shlomo, 2011, s. 89-93, Tab. 1; Özer, 2017, s. 49). Bu kaplar MÖ 6.-4. yüzyllarda daha da popüler hale gelmiştir (Zukerman \& BenShlomo, 2011, s. 91). Hellenistik Dönem'de (Thompson, 1934, s. 416, Fig. 102: E124) de kullanılmaya devam eden mortarların yazıtlı örneklerine Roma Dönemi'nde rastlanmaktadır (Hayes, 1967) ${ }^{13}$. Roma Dönemi'nde, özellikle mutfaklarda ezme işlemi için, pişmiş toprak mortarlardan ziyade taş mortarlar tercih edilmiştir (Hayes, 1967, s. 337). Geç Roma ve Bizans Dönemi’nde her iki mortarda (pişmiş toprak, taş/mermer) birlikte kullanılmıştır (Tek, 2003; Doğan, 2007; Amit \& Adler, 2018, s. 567, Fig. 14.7: 94-96).

Matteucci, Grek pişmiş toprak mortarlarının ilk olarak tahılı sslatmak ve yıkamak için, sonrasında ise

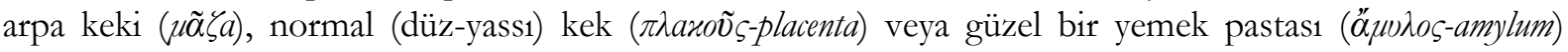
yapmak için tahılı işlemede (öğütme/ezme) kullanıldıklarını önerir (Matteucci, 1987, s. 246-252). Sapin, Levant Bölgesi'nde öncelikle yulaf lapası $(\dot{\alpha} \theta \dot{a} \varrho \eta)$ yapmak için mortarların tercih edildiğini söyler (Sapin, 1998, s. 110-117). Villing ise yulaf lapası dişında sebze ve bakliyat ürünlerinden yapılan püre ve çorbalarında mortarlarda yapılmış olduğunu belirtir (Villing, 2006, s. 35). Moritz'e göre mortarlardan küçük tahılların kabuklarının soyulması aşamasında yararlanılmıştır (Moritz, 1958, s. 151; Villing \& Pemberton, 2010, s. 613-614). Ancak bu soyma işlemi, mortar olmadan da, sslatılan tahıl ovularak yapılabileceği için Moritz'in bu savı pek desteklenmemiştir. MS 4. yüzyllda yaşamış Yunanlı doktor olan Oribasius ${ }^{14}$ haşlanmış darının mortarda suyla birlikte ezildiğini/ögütüldüğünü yazmıştır (Ori. Collec. med. IV.7.25). Aristophanes ekmeğin mortar içerisinde yoğrulduğundan söz eder. Aynı şekilde Oribasius'ta yoğurulması gerektiğinden bahsetmektedir. Cato ise placenta (düz-yassı) kek yapmak için taze koyun peynirinin ${ }^{15}$ bir mortar içerisinde yoğrulması gerektiğini şart koşmaktadır (Villing \& Pemberton, 2010, s. 614). Nemlendirilmiş ve güneşte kurutulmuş alphita ${ }^{16}$ (önceden pişirilerek kabuğu soyulmuş) bakliyat ve findıkla karıştırlıp mortarda ezilerek Yunanlıların bir çeşit yemeği olan maza (arpa keki) yapilmaktadır (Sapin, 1998, s. 110-117; Villing, 2006, s. 35). İngiltere'de bulunan mortarlar içerisindeki organik kalıntılar incelendiğinde önemli bilgilere ulaşılmışır. Bu çalışmaya göre Roma mortarlarının içinde bitkisel ve hayvansal kalıntılara rastlanmıştır. Araştırmacilar bunun sonucu olarak, Apicius ve Columella'nın yemek tarifini17 de dikkate alarak, mortarlar içerisinde yemek hazırlamak için etin (koyun?) baharat, yağ ve bitki yapraklarıly birlikte

\footnotetext{
11 Taş Örnekleri için bkz Sardis: Crawford, 1990, Fig. 59, 180, 266, 298, 309-310, 333; Patara: Korkut, 2002; Dardanos Tümülïiü (Troas): Tombul, 2006; Kourion: Megaw, 2007, s. 338, Fig. 7.5; Pamfilya ve Likya: Doğan, 2007; Allionai: Türkmen, 2009; Salla (Pannonia): Varga, 2010, s. 146, Fig. 1: 1-4; Perge: Çokay Kepçe, 2017, s. 24; Parion: Yıldızlı \& Ergürer, 2019; Asklepios, genelde

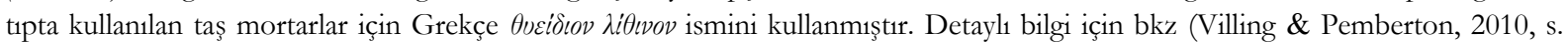
557 vd.)

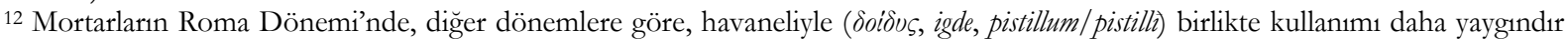
(Villing ve Pemberton 2010, 557 vd.).

${ }^{13}$ Yazıtlı örnekler ve yazıtlar için ayrıca bkz (Tek, 2003; Yangaki, 2009).

${ }^{14}$ Yazar hakkında ayrıntılı bilgi için bkz (Jagusiak vd., 2015, s. 127 vd.; Kokoszko vd., 2016, s. 355 vd.).

15 Yunanlılar ve Romalılar myttotos/myssotos ve moretum ismini verdikleri baharatlı (ezilmiș otlar, kimyon, kișniş, sirke, silphium, fındık, sarımsak vb.) peynirlerini işlemek için mortarları sıklıkla mutfaklarında kullanmışlardır (Villing, 2006, s. 34). İngiltere'de yapılan bir araştırmada Roma Dönemi mortariumlarında yaygın olarak süt yağı kalıntılarına rastlanmışır (Cramp vd., 2011, s. 1348, Fig. 6). Bu araştırma ile mortarların süt ürünleri (peynir, tereyağı?) işlemede kullanıldıkları düşüncesi doğrulanmaktadır.

${ }^{16}$ Emmer buğdayı (yabani buğday türü) için bkz (Demir, 2015, s. 1 vd.).

17 Tarif için ayrıca bkz (Cramp vd., 2011, s. 1341).
} 
harmanlandığı veya ezildiği önerisini getirmektedir (Cramp vd., 2011). Özetle, mortarlar Yunan ve Roma mutfağında çok amaçl1 ${ }^{18}$ kullanılan araç-gereçlerdendir.

Naukratis (Villing, 2006, s. 32, Fig. 3, 5-9) ve Samos Heraion'u (Villing, 2006, s. 35, Fig. 16) gibi kutsal alanlarda üzerinde tanrı ve tanrıçalara atıf yapan yazıtların yer aldığı mortarlar bulunmaktadır ${ }^{19}$. Bu mortarların kült yemeklerinin veya adaklıkların hazırlanmasında ve sunulmasında kullanılmıs olabilecekleri düşünülmektedir (Matteucci, 1987; Villing, 2006, s. 35 vd.; Villing, 2009, s. 322, 328-331; Villing \& Pemberton, 2010; Özer, 2017). Mortarların kuru gida (tahıl vb.) ve yağ (zeytin yağı?) ölçümüyle (ölçü birimi olarak kullanılması) ilişkisinin olabileceği şeklinde görüşlerde bulunmaktadır (Oren, 1984, s. 17; Greene vd., 2008, s. 705; Zukerman \& Ben-Shlomo, 2011, s. 88, dn.4; Greene vd., 2013, s. 28). Patara'daki bir mezarda bulunan taş mortarların yanında tıp ve kozmetik eşyalarla ele geçmesi bunların kozmetik ve tıp amaçlı malzemelerin karıştırılması veya ezilmesinde kullanılmış olabileceklerini göstermektedir (Korkut, 2002, s. 239-240, Abb. 7). Bazı taş mortarların metalleri ezmek için kullanıldığı da belirtilmektedir (Doğan, 2007, s. 65). Perge Batı Nekropolisi'nde ele geçen bir mortarda saptanan organik renk kalıntısı mortarların boya yapımında kullanıldıklarını düşündürmektedir (Çokay Kepçe, 2017, s. 24, M1.8) ${ }^{20}$. Mortarların eski camların ezilerek yenisinin üretiminde kullanıldığ da bilinmektedir (Demir, 1999, s. 11, 13) ${ }^{21}$. Bunlar dışında ölü gömme ritüelleri (Villing, 2006, s. 37; Zukerman \& Ben-Shlomo, 2011, dn.6), mezar hediyesi (Tombul, 2006, s. 255, Res. 2; Villing, 2006, s. 37; Krekovič, 2016) ${ }^{22}$, urne ${ }^{23}$, pithos ve amphora kapağ1 (Jacopi, 1931, s. 269, Fig. 294; Villing, 2006, s. 37, dn.122) olarak da kullanılmışlardır.

\section{Andriake Roma Dönemi Mortarları}

Çalışma konusu olan Andriake'de ortaya çıkarılmış Roma Dönemi'ne ait mortarlar ağız profillerine göre altı farklı tipte değerlendirilmiştir ${ }^{24}$.

\subsection{Tip 1 (Dramont D1, Hartley Tip 1, Riley Tip A, Olcese Tip 1, Quercia Tip 9)}

Tip 1 mortarlarından Andriake'de iki adet ele geçmiştir. Bu tip, içe doğru girinti yapan bir ağıza, dişta üzeri geniş ve hafif oval olan uç kısmı aşağı sarkık ağı kenarına ve kaideye doğru hafifçe daralan sığ bir gövdeye sahiptir (Kat. No: 1-2, Çizim 1: 1-2). Dişta ağızdan ağız kenarına geçiş hafif içbükey sı̆̆ bir yivle sağlanmaktadır. Andriake Tip 1 örneklerinin kaideleri eksiktir. Bu nedenle nasıl bir kaideye sahip olduklar1 konusunda yorum yapmak oldukça güçtür. Formun en belirgin özelliği ağız kısmının içe doğru girinti yapmasıdır. Tip 1 mortalarının ağız çapları $38-40 \mathrm{~cm}$ arasında değişmektedir. Kil renkleri çok soluk kahverengi ve pembe tonlarındadır. 1 kat. nolu örneğin astarı yokken, diğer örnek (Kat. No: 2) kırmızı tonlarında astara sahiptir. Tip 1 mortarlarının sık dokulu, gözeneksiz ve az gözenekli olan killerinde çok az miktarda orta ve küçük boyutta kuvars, çok az miktarda küçük boyutta şamot (grog) ${ }^{25}$, çok az miktarda küçük boyutta altın mika, az miktarda orta ve küçük boyutta gümüş ve altın mika, az miktarda orta ve küçük boyutta kuvars, yoğun miktarda orta ve küçük boyutta taşçk, yoğun miktarda çok küçük boyutta gümüş mika katkısı bulunmaktadır.

Andriake Tip 1 örneklerinin yakın benzerlerine Berenike/Libya (Riley, 1979, Fig. 112: 668), Güney Yorkshire/İngiltere (Buckland vd., 1980, s. 150, Fig. 3: 1), Albintimilium/İtalya (Olcese, 1993, s. 132, Fig. 20: 336-337), Roma (Olcese, 2003, s. 35, 150, Fig. 27: XXXIX.3, Tav. XXXIX: 3), Ilok/Hirvatistan (Jelinčić, 2003, s. 87, Pl. 2: 14), via Sacchi/İtalya (Quercia, 2008, s. 208, 226, Fig. 5: 9), Patara (Özdemir,

\footnotetext{
18 Diğer fonksiyonları için ayrıca bkz (Symonds, 2012).

19 Pedasa Athena kutsal alanında da ele geçen yazıtsız mortarlar için bkz (Özer, 2017, s. 41 vd).

${ }^{20}$ Dardanos Tümülüsü’nde ele geçen ve içinde pembe boya olan örnek için ayrıca bkz (Tombul, 2006, s. 255, 259, Res. 2).

${ }^{21}$ Ayrica bkz (Гıхүхахฑ 2008).

22 Salamis'teki mezarlarda ele geçen örnekler için bkz (Karageorghis, 1967, Pl. 41, 125; Karageorghis, 1970, Pl. 53, 203; Karageorghis, 1973, Pl. 41, 47, 51, 233; Karageorghis, 1978, Pl. 7, 44).

${ }^{23}$ Schwabmünchen/Rapis'te bir mezarlıkta ele geçen iki mortar ünik bir kullanıma sahiptir. Diğerine göre büyük çaplı mortar içine ölü külleri konularak urne amaçlı kullanılmış, diğeri ise onun üzerine kapak olarak yerleştirilmiştir. Detaylı bilgi için bkz (Krekovič, 2016, s. 516-517, Fig. 5).

${ }^{24}$ Mortarların çalışma iznini veren Myra-Andriake Kazıları başkanı değerli hocam Prof. Dr. Nevzat Çevik’e teşekkürü bir borç bilirim.

${ }^{25}$ Seramik kırı̆ 1 ve/veya tozu.
} 
2009, s. 187, Lev. 36: 356), Alpes-Maritimes/Fransa (Pellegrino, 2009, s. 175, Fig. 7b: 4), Segobriga/İspanya (Fernándes \& Uceda, 2011, s. 130, Fig. 2: 22, 35-36, 39-40), Nepi/İtalya (Mills \& Rajala, 2011, s. 184, Fig. 20), Cremona/İtalya (Ragazzi \& Frontori, 2018, Tav. 57: 3, 58: 1), Drôme/Valensiya (Gilles, 2013, s. 174, Fig. 5: 2), Salla/Zalalövö (Varga, 2010, s. 180, Fig. 26: 244) ve Nauportus/Vrhnika (Berden vd., 2019, s. 55, Pl. 7: 1)'ta rastlanmaktadır. Analojik karşılaştırma neticesinde Tip 1 mortarları için MÖ 1. yüzyıl sonu ile MS 2. yüzyıl tarihi önerilebilir.

Genel olarak İtalya'da üretilen (Riley, 1979, s. 294) bu forma ait mortarların ${ }^{26}$ son yllarda yapilan araştırmalarda Pannonia Bölgesi'nde de üretildiği anlaşılmıştır (Jelinčić, 2003, s. 81; Varga, 2010). MÖ 1. yüzyllın sonunda ortaya çıkan bu form MS 4. yüzyıla kadar kullanılmıştır. Özellikle MÖ 1. yüzyıl ile MS 2. yüzyıl arasında Batı ve Doğu Akdeniz'de oldukça yaygın olarak görülmektedir (Olcese, 1993, s. 131; Quercia, 2008, s. 208 ${ }^{27}$. Andriake Tip 1 mortarlarının kil renkleri ve katkıları yakın benzerleriyle aynı özelliklere sahiptir. Dolayısıyla Tip 1 mortarlarının üretim yeri İtalya olmalıdır. Andriake Limanı'nda ele geçen bu tip mortarlar özellikle MÖ 1. yüzyıl sonlarından itibaren ana kent Myra’nın İtalya ile ticari ilisskide olduğunun bir göstergesidir.

\subsection{Tip 2}

Andriake'de bu tipe ait bir adet mortar ortaya çıkarılmışır (Kat. No: 3, Çizim 1: 3). Bu tip üzeri oval içe dönük ağızlı ve kaideye doğru hafif daralan kalın cidarlı sı̆̆ gövdelidir. Andriake Tip 2 mortarının ağız üzerinde baskı tekniğinde yapılmış dikdörtgen çerçeve içerisinde ardışık devam eden yedi adet kısa kesik çizgi motifi bulunmaktadır. Kaidesi eksiktir. Ağız çapı 34 cm'dir. Açık kırmızı kili sık dokulu ve az gözeneklidir. Kil içerisinde çok az miktarda küçük boyutta kireç ve az miktarda orta boyutta taşçık ve şamot katkısı vardır. Astarı sarımsı kırmızı renktedir.

Andriake Tip 2 mortarının benzerine rastlanmamıştır. Ele geçtiği alanda da birlikte bulunduğu kontekst eserlerin olmaması tarihlendirilmesini zorlaştırmaktadır. Horrea Hadriani/Granarium önünde ele geçen mortarın yapıyla ilişkili olduğu varsayıldığında Tip 2 örneğini için, Horrea'nın inşası ve yapının kazısında ele geçen en yoğun buluntu grubunun tarihi (Bulut \& Şengül, 2014, s. 85) düşünüldüğünde, MS 2-4. yüzyll tarihi önerilebilir. Bu örnek kil içeriği bakımından Myra'da ele geçen Geç Roma seramik gruplarıyla benzerlik göstermektedir ${ }^{28}$. Dolayısıyla Tip 2 Myra'da üretilen yerel bir form olmalıdır.

\subsection{Tip 3}

Tip 3'ten Andriake'de bir adet ele geçmiştir (Kat. No: 4, Çizim 1: 4). Üzeri hafif iç bükey dik bir ağıza, dışta kalınlaştırılmış oval ağız kenarına ve kaideye doğru daralan derin bir gövdeye sahiptir. Diğer tiplerden farklı olarak bu tip mortarda dikey halka bir kulp bulunmaktadır. Kalın kulp ağız kenarı ile gövdeye tutturulmuştur. Kaidesi kırıktır. Ağı çapı 49+ cm'dir. S1k dokulu ve gözeneksiz olan sarımsı kırmızı renkteki kili çok az miktarda büyük boyutta taşçı, az miktarda küçük boyutta şamot, yoğun miktarda orta ve küçük boyutta taşçık ve kireç katkısı içermektedir. Tip 3 mortarının astarı yoktur.

Andriake Tip 3 mortarının MS 5. yüzylla tarihlenen yakın benzerine ${ }^{29}$ Ras el Bassit(Suriye)'te rastlanmaktadır. Tip 3 içinde aynı tarih önerilebilir.

\subsection{Tip 4 (Guisan Tip C, Varga Tip A)}

İtalyan mortarları (Zsidi \& Balla, 2000, s. 249) olarak bilinen bu tipe ait Andriake'de bir adet mortar ele geçmiştir (Kat. No: 5, Çizim 2: 1). Hafif yuvarlatılmış içe dönük ağız, dışta üzeri hafif oval uç kısmı yuvarlatılmış aşağı dönük geniş ve uzun bir ağız kenarı ve kaideye doğru daralan derin ince cidarlı gövde bu tip mortarların genel özelliklerindendir. Ağızdan ağız kenarına geçiş içbükey sı̆̆ bir yivle sağlanmaktadır. Kaidesi kırıldığı için nasıl olduğu konusunda herhangi bir yorum yapılamamaktadır. Ağız çapı 24 cm'dir. S1k dokulu ve gözeneksiz olan kili kırmızı renktedir. Kilinde az miktarda küçük boyutta taşçık ve yoğun miktarda küçük boyutta kireç katkısı bulunmaktadır. Astarı yoktur.

\footnotetext{
${ }^{26} \mathrm{Bu}$ tip mortarların genelde İtalya'dan ithal edildikleri belirtilmektedir (Olcese, 1993, s. 131).

${ }^{27}$ Bu tipin ele geçtiği kentler için ayrıca bkz (Olcese, 1993, s. 131).

28 Yerel üretim örneklerin kil özellikleri için bkz (Öz, 2020).

${ }^{29}$ Mills bu örneğin benzerini mortar ve/veya çanak olarak değerlendirmiştir (Mills, 2014, s. 27, Fig. 10: M32.1 Ba1.12).
} 
Andriake Tip 4 mortarının yakın benzerlerine Aquincum/Budapeşte (Zsidi \& Balla, 2000, Fig. 3: D), Vieux-Lyon/Fransa (Vallet \& Lemaitre, 2008, s. 242, Fig. 40: 118/122), Salla (Varga, 2010, s. 152, Fig. 5: 35-36) ve Ilişua/Romanya (Gaiu, 2016-2017, s. 93, Pl. IX: 43)'da rastlanmaktadır. Benzer örnekler genel olarak MS 1. yüzyıl sonu ile 3. yüzyıl arasına tarihlenmektedir. Tip 4 mortarı içinde aynı tarihler arası önerilebilir.

\subsection{Tip 5}

Andriake'de Tip 5'e ait üç adet mortar ortaya çıkarılmışıtır (Kat. No: 6-8, Çizim 2: 2-4). Bu tip içe dönük ağıza, dışta üzeri oval hafif aşağı dönük geniş ağız kenarına ve kaideye doğru daralan dairesel bir gövdeye sahiptir. 7 kat. nolu mortar eksik kaidesi dışında tüme yakındır. Mortarın ağız kenarının bir bölümüne her iki kenarı yükseltilmiş üçgeni anımsatan akıtacak yapılmıştır (Çizim 2: 3). İncelenen mortarlardan ikisinin ağız kenarında yazıt yer almaktadır (Kat. No: 7-8, Çizim 2: 3-4). İlk mortarın ağız kenarına dikdörtgen çerçeve içerisinde iki satırdan oluşan ve üç kez tekrarlanan EIPHNAI EYT'YXI*

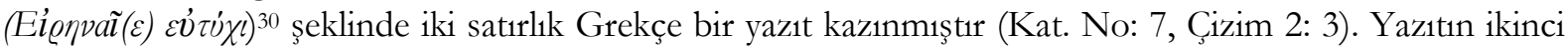
satırının son harfi tam olarak okunamamaktadır. Yangaki benzer yazıtların sonunda genelde asma yaprağının ${ }^{31}$ yer aldığını belirtir. Yazıt "Ey Eirenaios muvaffak ol"32 şeklinde iyi şans dileği bildirmektedir 33 . Bu yazıtın benzerlerine Atina Agoras1, Myriandros/Suriye, Seleucia Pieria/Antakya, Bylos/Suriye, Deir elQal'a/Lübnan, Anthedon/Filistin, Gaza, Meroth/Filistin, Tell 'Atar/Suriye, Cheikh Zouéde/Filistin, Ras el Bassit, Alexandria/Misir, Achmim-Panopolis/Misir, Strazburg/Fransa, Anemurium, Risingham/İngiltere (Hayes, 1967; Vallerin, 1994, s. 176; Yangaki, 2009, s. 268 vd.) ve son olarak da Myra (Lykia)'da rastlanmıştır. 8 kat. nolu mortarın ağız kenarında da çerçeve içerisinde birbirine zıt yönde yan

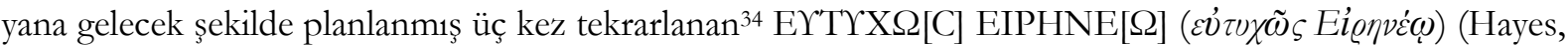
1967, s. 340) yazısı içeren iki satır Grekçe yazıt yer almaktadır (Çizim 2: 4). Her iki yazıt satırının son harfleri okunamasa da benzerlerinden yararlanılarak tamamlanabilmiştir. Yazıt "Eireneos oğgu Eutykhos" olarak çevrilmiştir (Tek, 2003, s. 397, Tablo 1). Bu yazıtın, 7 kat. nolu mortardaki yazıta benzer anlamlar taşıyan ikincil bir form olarak mortarlar üzerine kazınmış olduğu düşünülmektedir (Yangaki, 2009, s. 250 vd.). Yazıtların üretici/atölye ya da özel bir kişiyi mi? tanımladı̆̆1 konusu üzerine tartısmalar devam etmektedir (Yangaki, 2009) 35. Bu yazıtları taşıyan eşyalar daha çok hediye olarak bir başkasına verilmiş, üzerindeki isimde eşyayı hediye edeni hatırlatması için yapılmış olmalıdır (Yangaki, 2009, s. 259). Tüm bu tartışmalar sonucunda uzlaşılan husus; yazıtların daha çok atölye (üretici/usta) (Hayes, 1967, s. 337) ya da onu hediye edeni işaret ettiği yönündedir. Ayrıca bu yazıtların hem üreticisine hem de alıcısına koruyucu bir güç sunduğu da ifade edilmektedir (Yangaki, 2009, s. 263). Yangaki, yazıtların etrafinı kimi zaman asma dallarının çevrelediğini, bununda nazardan koruduğuna inanıldığı için yapıldığını savunmaktadır (Yangaki, 2009, s. 251-252). 8 kat. nolu mortarın üzerindeki yazıt üretici veya hediye edenin ismini veriyor olmalıdır. Yazıtın benzerleri (Hayes, 1967, s. 344; Riley, 1975, s. 43, Fig. 5; Groh, 1978, s. 167, 169, Pl. 1: 4; Yangaki, 2009, s. 268-270) Ras el Bassit, Deir el-Qal'a, Seleucia Pieria, Myriandros, Anthedon, Caesarea/Filistin, Alexandria, Anemurium, Lebena/Girit, Kahire/Misır, Kıbris ve son olarak da Myra (Lykia)'da bulunmaktadır. Andriake Tip 5 mortarlarının ağız çapları 29.8-31 cm arasında değişmektedir. Açık kırmızı, koyu kahverengi ve kırmızımsı kahverengi renk tonlarına sahip olan Tip 5 mortarlarının biri dışında (Kat. No: 8) diğerlerinde astar görülmemektedir. Seyrek ve sık dokulu, gözenekli ve gözeneksiz gibi özelliklere sahip killerinde az miktarda küçük boyutta siyah ince kum tanecikleri, taşçık ve gümüş mika, yoğun miktarda büyük, orta ve küçük boyutta taşçık, siyah ince kum tanecikleri ve kireç katkısı vardır.

\footnotetext{
30 Mortarlar üzerinde görülen "EYTYXI (

31 Asma yaprağı dışında sarmaşık yaprağının da yapıldığı bilinmektedir (Hayes, 1967, s. 338).

32 Yazıtın çevirisini yapan Myra-Andriake Kazıları heyet üyesi Epigraf Doç. Dr. Burak Takmer hocama teşekkür ederim.

33 Yangaki'ye göre Suriye mortarları üzerine yazılan yazıtların çoğu iyi şans ve/veya şanslar dileğini iletmektedir (Yangaki, 2009, s. 249-250).

34 Mortarın bir kısmı ele geçtĭgi için yazıt şu anki mevcut halinde üç kez tekrarlanmaktadır. Tüm halinde kaç kez tekrarlanmış olabileceği net değildir. Mortarın çapı düşünülerek hesaplama yapıldığında yazıtın iki satır olarak dokuz kez tekrarlanmış olabileceği öngörülmektedir.

35 Atina'da MS 3. yüzyılın ortalarından 5. yüzyılın ilk yarısına kadar faaliyet gösteren Eutyches kandil atölyesinde buna benzer bir yazıt imza olarak kullanılmışır (Karivieri, 1996, s. 95-98).
} 
Suriye mortarları olarak bilinen bu tip için MS 3. yüzyll ile 4. yüzyllın ilk yarısı tarihi önerilmektedir (Hayes, 1967, s. 337 vd.). Ancak son yıllarda yapilan çalışmalarla bu tarih daha ileriye (MS 6. yüzyıl ortaları) götürülmüştür (Tek, 2003, s. 403, Şek. 4; Ramos vd., 2007, s. 96, Fig. 6: 31; Oren-Paskal, 2008, s. 36, Fig. 2: 13; Mills \& Reynolds, 2014, s. 140, Fig. 6: 24). Andriake Tip 5 mortarlarının yakın benzerlerine Caesarea (Riley, 1975, s. 41-42, no.66), Caesarea Maritima (Groh, 1978, s. 167, 169, Pl. 1: 7), Salla (Varga, 2010, s. 147, 151, Fig. 2: 12, 4: 24), Viminacium/Strbistan (Raičković, 2012, s. 151, Fig. 5: 33), Shuni/İsrail (Vincenz, 1998, s. 73, Fig. 3), Lagos/Portekiz (Ramos vd., 2007, s. 96, Fig. 6: 31), Tapınak Dağ1/İsrail (Vincenz, 2011, s. 191, Fig. 8.2: 11), Dacia (Hortopan, 2011, Pl. I: 2, 4), Ras el Bassit (Mills \& Reynolds, 2014, s. 140, Fig. 6: 24), Yafo/Jaffa-İsrail (Gendelman, 2020, s. 168, Fig. 5: 9), Berenike (Riley, 1979, Fig. 112: 669), Bat Galim/İsrail (Oren-Paskal, 2008, s. 36, Fig. 2: 13), Tunus (Tahar vd., 2018, s. 176, Fig. 5: 52) ve Arykanda (Tek, 2003, s. 403, Şek. 4)'da rastlanmaktadır. Benzerleri için önerilen genel tarih MS 3-6. yüzyıl arasıdır. Andriake Tip 5 örnekleri için ise, Suriye mortarlarının Doğu eyaletlerinde en yaygın olduğu zaman dilimi olan MS 3-4. yüzyll tarihi önerilmektedir.

Suriye mortarlarının ilk grubunun koyu kahverengi ve kırmızı renk tonlarında olan killeri kum ve kireç katkılı olup mika içermemektedir (Hayes, 1967, s. 337 vd.; Groh, 1978, s. 165 vd.). Tip 5 örnekleri Suriye mortarlarının genel kil özelliklerine sahipken, kil içeriklerinde bulunan taşçık ve gümüş mika katkısı sebebiyle de ayrılmaktadır. Bu nedenle Tip 5 mortarlarının Suriye'de mi? yoksa Myra'da mı? üretildikleri konusu sonraki yıllarda yapılacak petrografik analizlerle netleşecektir.

\subsection{Tip 6}

Tip 6'ya ait Andriake'de dört adet mortar ele geçmiştir (Kat. No: 9-12, Çizim 3: 1-4). İçe dönük bir ağız, dışta uç kısmı aşağı sarkık geniş ağız kenarı, ağız kenarından gövdeye geçişte dış bükey bir profil (Çizim 3: 4) ve kaideye doğru daralan gövde bu tip mortarların genel özelliklerindendir. Değerlendirilen mortarların kaideleri kırıktır. Bu tipin en belirgin özelliği ağız kenarının üzerinin düz bir profile sahip olmasıdır. Ağız çapları 32-44 cm arasında değişmektedir. Seyrek dokulu, gözenekli ve az gözenekli olan killeri kırmızı renktedir. Killerinde çok az miktarda küçük boyutta kuvars, az miktarda küçük boyutta şamot, gümüş mika ve kireç, yoğun miktarda orta ve küçük boyutta taşçı, kireç ve gümüş mika, çok yoğun miktarda büyük, orta ve küçük boyutta taşçık katkısı görülmektedir. 10 ve 11 kat nolu örneklerin astarı kırmızı renkte iken diğerlerinde (Kat. No: 9, 12) astar yoktur.

Andriake Tip 6'ya ait mortarlardan 10, 11 ve 12 kat. nolu örneklerin benzerlerine Atina Agorası (Hayes, 1967, s. 340, Fig. 3: 5), Abu Mena/Misir (Hayes, 1967, s. 340, Fig. 3: 6), Caesarea (Riley, 1975, s. 36-37, no. 42), Bat Galim (Oren-Paskal, 2008, s. 36, Fig. 2: 15), Ras el Bassit (Mills, 2014, s. 27, Fig. 10: M32.2 B1.2, M32.1 Ba1.13; Mills \& Reynolds, 2014, s. 141, Fig. 7: 30) ve Hatay (Kereci, 2019, s. 169, Lev. 8: 85)'da rastlanmıştır. Diğer mortarın benzeri bulunamamıştır (Kat. No: 9). Benzerleri için verilen MS 4-6. yüzyıl tarihi Tip 6 içinde önerilebilir.

Tipk1 Tip 5 gibi bu tip mortarlarında Suriye üretimi oldukları düşünülmektedir (Hayes, 1967; Riley, 1975, s. 37; Oren-Paskal, 2008, s. 35 vd.). Tip 6 mortarları Suriye mortarlarından kil içerikleri bakımından farklıdır. $\mathrm{Bu}$ farklılık Tip 6 örneklerinin Myra'da yerel olarak üretilmişs? olabileceklerini düşündürmektedir ${ }^{36}$.

\section{Sonuç}

Likya Bölgesi’nin önemli kentlerinden Myra’nın liman yerleşimi olan Andriake, Antalya İli, Demre İlçesi'nde yer alan günümüzde Kokarçay (Andriakos)'ın denize döküldügü Çayağzı mevkiinde kurulmuştur. Limandaki kazı çalışmaları Prof. Dr. Nevzat Çevik başkanlığında geniş bir ekiple 2009 yıllından bu yana sürdürülmektedir. Bu kazı çalısmaları limanda bulunan Horrea Hadriani/Granarium, Agora/Plakoma, Germanicus Meydanı, Liman Yapıları, Sinagog, Şarap İşlikleri, Doğu ve Batı Hamam, A ve B Kilisesi, Onurlandırma Anıtları ve Güneydoğu Nekropolü gibi birçok yapıda yürütülmüştür. Kazılar sonucunda Andriake limanının MÖ 4. yüzyllın sonundan MS 7. yüzyılın ortalarına kadar kesintisiz iskân edildiği anlaşılmaktadır.

\footnotetext{
${ }^{36}$ Tip 6 mortarları Myra’daki Geç Roma seramiklerinin kil katkılarına benzer özelliklere sahiptir. Ayrıntılı bilgi için bkz (Öz, 2020).
} 
Andriake'de 2009-2010, 2012 ve 2016 yllarında Şarap İşlikleri, 2015 Yllı İşlik Kazısı Atık Toprağ1, Horrea Hadriani/Granarium, Sinagog, Horrea Hadriani/Granarium Önü ve Liman Yapılarında gerçekleştirilen kazı çalışmalarında ele geçen toplam 12 adet pişmiş toprak mortar bu çalışma kapsamında

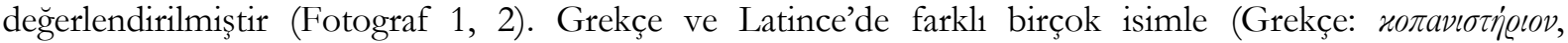

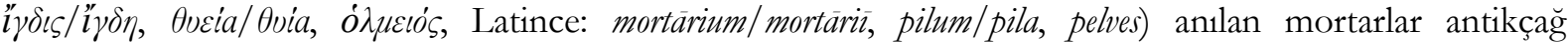
mutfağında çok amaçlı kullanılan önemli kaplardandır. Tarihsel geçmişi Paleolitik Dönem'e kadar giden mortarlar bilinen formuna MS 8. yüzyılın sonlarından itibaren kavuşmuştur. Oldukça geniş bir coğrafyada (Levant, Fenike, Doğu Akdeniz, Ege, Kıbrıs, Mısır, Kuzey Suriye, Güney Anadolu kıyıları, Almanya, Britanya, Galya ve Pannonia Bölgesi vb.) görülen mortarlar mutfakta ekmek, yulaf lapası, kek, püre, çorba ve peynir yapımı, etlerin marinasyonu, çeşitli tahıl, bitki ve baharatların ezilerek öğütülmesi gibi birçok farklı işlevde kullanılmıştır. Mutfak dışında ise kutsal törenlerde, tıp ve kozmetikte, kuru gıdaların ölçümünde, cam ve bazı metallerin ögüutülmesinde, boya yapımında, urne olarak, ölü gömme ritüellerinde, mezar hediyesi, pithos ve amphora kapağ olarak birçok farklı yer ve alanda kullanım görmüştür. Andriake'de ele geçen mortarların yukarıda sayılan kullanımları dışında, özellikle küçük murekslerin ezilerek mor boyasının ${ }^{37}$ çıarılmasında kullanılmıs olabileceği düşünülmektedir. Perge'de ele geçen bir mortarda saptanan organik renk kalıntısı bu düşüncemizi destekleyici örneklerdendir (Çokay Kepçe, 2017, s. 24, M1.8). Myra'nın ismini de aldığı mersin bitkisinden (Commiphora myrrha) üretilen mür yağının kent için önemi düşünüldüğünde, bu mortarlar mür yağının çıkarılmasında da kullanılmış olmalıdır. Kazılarda şimdiye dek havan eline rastlanmasa da az sayıda ezme taşı olduğu düşünülen eser açığa çıkarılmıştır. Ancak bu ezme taşlarının incelenen mortarların pişmiş toprak olmalarından dolayı birlikte kullanımları pek mümkün gözükmemektedir. Dolayısıyla Andriake'deki mortarlarda ezilen maddelerin ne ile ezildikleri konusu şu an için yanıtsız kalmaktadır.

Andriake'de bulunan Roma Dönemi mortarları ağız profillerine göre altı farklı tipe ayrılmıştır. Tip 1 mortarlarından iki örnek bulunmaktadır (Kat. No: 1-2, Çizim 1: 1-2). MÖ 1. yüzyll sonu ile MS 2. yüzyıl arasına tarihlenen bu tip, literatürde İtalyan mortarları olarak bilinmektedir. Andriake Tip 1'in yakın benzerlerine Berenike, Güney Yorkshire, Albintimilium, Roma, Ilok, via Sacchi, Alpes-Maritimes, Segobriga, Nepi, Cremona, Drôme, Salla ve Nauportus'ta rastlanmaktadır. Tip 2'ye ait tek örnek ele geçmiştir (Kat. No: 3, Çizim 1: 3). MS 2-4. yüzylla tarihlenen bu tipin benzerine rastlanmamıştır. Andriake Tip 2 mortarının sık dokulu ve az gözenekli, kireç, taşçı ve şamot katkılı kili Myra-Andriake seramiklerinin kil içerikleriyle $(\overparen{\mathrm{O} z}, 2020)$ benzerlik göstermektedir. Dolayısıyla tip 2 mortarının Myra'da üretilmiş yerel bir tip olduğu düşünülmektedir. Andriake Tip 3'e ait tek örnek MS 5. yüzylla tarihlenmektedir (Kat. No: 4, Çizim 1: 4). Yakın benzerine Ras el Bassit (Suriye)'te rastlansa da bu tipin nerede üretilmiş olabileceği şu an için net değildir. Yine İtalyan mortarları olarak bilinen Andriake Tip 4 mortarlarından bir adet örnek bulunmaktadır (Kat. No: 5, Çizim 2: 1). MS 1. yüzyıl sonu ile 3. yüzyıl arasına tarihlenen Tip 4 mortarının yakın benzerlerine Aquincum, Vieux-Lyon, Salla ve Ilişua'da rastlanmıştır. Andriake'de Tip 5'e ait üç adet mortar değerlendirilmiştir (Kat. No: 6-8, Çizim 2: 2-4). Bunlardan ikisinin ağız kenarında iki satır Grekçe yazıt yer almaktadır (Kat. No: 7-8). 7 kat. nolu mortarın

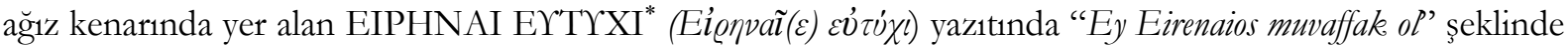
iyi şans dileği bildirilmektedir (Çizim 2: 3). 8 kat. nolu mortarın ağız kenarında ise EYTTX $\Omega[C]$

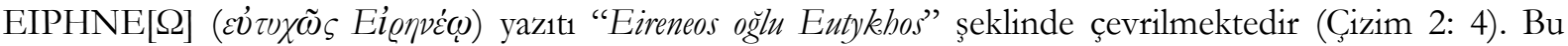
yazıtında ilk örnekte olduğu gibi iyi şans anlamında kullanıldı̆̆ ileri sürülse de (Yangaki, 2009, s. 250 vd.), mortarı yapan üretici/atölye veya onu hediye edenin ismini ifade ediyor olmalıdır. Tip 5 mortarları MS 3-4. yüzyıla tarihlenmektedir. Benzerlerine Caesarea, Salla, Viminacium, Shuni, Lagoz, Tapınak Dağı (İsrail), Dacia, Ras el Bassit, Yafo/Jaffa, Berenike, Bat Galim, Tunus ve Arykanda'da rastlanmıştır. Andriake Tip 6 mortarlarından dört adet ele geçmiştir (Kat. No: 9-12, Çizim 3: 1-4). MS 4-6. yüzyıla tarihlendirilen bu tipin benzerlerine Atina Agoras1, Abu Mena, Caesarea, Bat Galim, Ras el Bassit ve Hatay'da rastlanmaktadır. Andriake Tip 5 ve Tip 6 mortarları literatürde Suriye mortarları olarak bilinmektedir. Ancak bu iki tipin kil içeriği benzerlerinden farkllık göstermektedir. Dolayısıyla Tip 5 ve Tip 6

${ }^{37}$ Andriake'deki mureks atölyesi ve boya üretimi ile ilgili ayrıntılı bilgi için bkz (Aygün, 2012). 
örneklerinin Suriye'de mi? yoksa Myra'da mı? üretildikleri konusu sonraki yıllarda yapılacak petrografik analizlerle netleşecektir.

Andriake mortarlarının incelenmesiyle birlikte Myra'nın limanı aracıllğıyla İtalya ve Suriye ile ticari ilişkide olduğu görülmektedir. Ayrıca bu çalışma Likya Bölgesi mortar literatürüne yeni tipler ekleyerek kent ve bölgenin seramik çalısmalarına katkıda bulunmaktadır.

\section{Katalog}

Kat. No/ Çizim No: 1/ 1:1

Tip: Tip 1

Buluntu Yeri/ Seviye: Şarap İşliği 1/C (Dolgu)

Ölçüler: A.Ç.: $40 \mathrm{~cm}$, Kor. Y.: $4.9 \mathrm{~cm}$

Kil: 10 YR 8/3 (soluk kahverengi), sık dokulu, az gözenekli, yoğun miktarda orta ve küçük boyutta taşçık, çok az miktarda orta ve küçük boyutta kuvars, çok az miktarda küçük boyutta şamot (grog), az miktarda orta ve küçük boyutta gümüş ve altın mika katkılı kil. Astar: Yok.

Tanım: Kırık ve eksik durumda mortar ağız-gövde parçası.

Karş1laştırma: Riley, 1979, Fig. 112: 668; Buckland vd., 1980, s. 150, Fig. 3: 1; Olcese, 1993, s. 132, Fig. 20: 336-337; Olcese, 2003, s. 35, 150, Fig. 27: XXXIX.3, Tav. XXXIX: 3; Jelinčić, 2003, s. 87, Pl.2: 14; Quercia, 2008, s. 208, 226, Fig. 5: 9; Pellegrino, 2009, s. 175, Fig. 7b: 4; Fernándes \& Uceda, 2011, s. 130, Fig. 2: 22, 35-36, 39-40; Ragazzi \& Frontori, 2018, Tav. 57: 3, 58: 1; Berden vd., 2019, s. 55, Pl. 7: 1.

Tarih: MÖ 1. yüzyıl sonu ile MS 2. yüzyıl

Kat. No/ Çizim No: 2/ 1:2

Tip: Tip 1

Buluntu Yeri/ Seviye: Sinagog 1 Nolu Açma, $-100 /-180 \mathrm{~cm}$

Ölçüler: A.Ç.: $38 \mathrm{~cm}$ (iç), Kor. Y.: $3.9 \mathrm{~cm}$

Kil: 5 YR 7/4 (pembe), sık dokulu, gözeneksiz, çok az miktarda küçük boyutta şamot (grog), az miktarda orta ve küçük boyutta kuvars, yoğun miktarda çok küçük boyutta gümüş mika, çok az miktarda küçük boyutta altın mika, çok az miktarda orta boyutta taşçık katkılı kil. Astar: 2.5 YR 5/8 (kırmızı).

Tanım: Kırık ve eksik durumda mortar ağız-gövde parçası.

Karş1laştırma: Riley, 1979, Fig. 112: 668; Buckland vd., 1980, s. 150, Fig. 3: 1; Olcese, 1993, s. 132, Fig. 20: 336-337; Olcese, 2003, s. 35, 150, Fig. 27: XXXIX.3, Tav. XXXIX: 3; Jelinčić, 2003, s. 87, Pl.2: 14; Quercia, 2008, s. 208, 226, Fig. 5: 9; Özdemir, 2009, s. 187, Lev. 36: 356; Pellegrino, 2009, s. 175, Fig. 7b: 4; Varga, 2010, s. 180, Fig. 26: 244; Mills \& Rajala, 2011, s. 184, Fig. 20: M02 M1.2; Fernándes \& Uceda, 2011, s. 130, Fig. 2: 22, 35-36, 39-40; Gilles, 2013, s. 174, Fig. 5: 2; Ragazzi \& Frontori, 2018, Tav. 57: 3, 58: 1

Tarih: MÖ 1. yüzyıl sonu ile MS 2. yüzyll

Kat. No/ Çizim No: 3/ 1:3

Tip: Tip 2

Buluntu Yeri/ Seviye: Horrea Hadriani/Granarium Önü 2-7 Nolu Açma Arası Kesit

Ölçüler: A.Ç.: $34 \mathrm{~cm}$ (iç), Kor. Y.: $6.6 \mathrm{~cm}$

Kil: 10 R 6/8 (açık kırmızı), sık dokulu, az gözenekli, az miktarda orta boyutta taşçık ve şamot (grog), çok az miktarda küçük boyutta kireç katkılı kil. Astar: 5 YR 5/6 (sarımsı kırmızı). Yüzeyde yer yer kireç ve toprak patinası görülmektedir.

Tanım: Kırık ve eksik durumda mortar ağız-gövde parçası.

Karşılaştırma: -

Tarih: MS 2-4. yüzyıl

Kat. No/ Çizim No: 4/ 1:4

Tip: Tip 3

Buluntu Yeri/ Seviye: 2015 İşlik Kazısı Atık Toprağı

Ölçüler: A.Ç.: 49+ cm (iç), Kor. Y.: $9.5 \mathrm{~cm}$ 
Kil: 5 YR 5/6 (sarımsı kırmızı), sık dokulu, gözeneksiz, az miktarda küçük boyutta şamot (grog), yoğun miktarda orta ve küçük boyutta taşçık, çok az miktarda büyük boyutta taşçık, yoğun miktarda küçük boyutta kireç katkılı kil. Astar: Yok.

Tanım: Kırık ve eksik durumda mortar ağız-gövde parçası.

Karşılaştırma: Mills, 2014, s. 27, Fig. 10: M32.1 Ba1.12.

Tarih: MS 5. yüzy1l

Kat. No/ Çizim No: 5/ 2:1

Tip: 'Tip 4

Buluntu Yeri/ Seviye: Şarap İşliği Toplama Çukuru, -335/-350 cm (Dolgu)

Ölçüler: A.C..: $24 \mathrm{~cm}$ (iç), Kor. Y.: $5.2 \mathrm{~cm}$

Kil: 2.5 YR 5/8 (kırmızı), sık dokulu, gözeneksiz, yoğun miktarda küçük boyutta kireç, az miktarda küçük boyutta taşçık katkılı kil. Astar: Yok.

Tanım: Kırık ve eksik durumda mortar ağız-gövde parçası.

Karşılaştırma: Zsidi \& Balla, 2000, Fig. 3: D; Vallet \& Lemaitre, 2008, s. 242, Fig. 40: 118/122; Varga, 2010, s. 152, Fig. 5: 35-36; Gaiu, 2016-2017, s. 93, Pl. IX: 43.

Tarih: MS 1. yüzy1l sonu ile 3. yüzyıl

Kat. No/ Çizim No: 6/ 2:2

Tip: Tip 5

Buluntu Yeri/ Seviye: Şarap İşliği Toplama Çukuru (Batı İşlik), -335/-350 cm

Ölçüler: A.C..: $30.4 \mathrm{~cm}$, Kor. Y.: $8.2 \mathrm{~cm}$

Kil: 2.5 YR 6/6 (açık kırmızı), sık dokulu, gözeneksiz, yoğun miktarda küçük boyutta kireç, az miktarda küçük boyutta taşçı ve siyah kum tanecikleri katkılı kil. Astar: Yüzeydeki yoğun kireç patinasından dolayı görülememektedir.

Tanım: Kırık ve eksik durumda mortar ağız-gövde parçası.

Karş1laştırma: Hayes, 1967, s. 340, Fig. 3: 2; Riley, 1975, s. 41-42, no.66; Groh, 1978, s. 167, 169, Pl. 1: 7; Riley, 1979, Fig. 112: 669; Vincenz, 1998, s. 73, Fig. 3; Ramos vd., 2007, s. 96, Fig. 6: 31; Varga, 2010 , s. 147, 151, Fig. 2: 12, 4: 24; Vincenz, 2011, s. 191, Fig. 8.2: 11; Hortopan, 2011, Pl. I: 2, 4; Raičković, 2012 , s. 151, Fig. 5: 33; Mills \& Reynolds, 2014, s. 140, Fig. 6: 24; Tahar vd., 2018, s. 176, Fig. 5: 52; Gendelman, 2020, s. 168, Fig. 5: 9.

Tarih: MS 3-4. yüzy1

Kat. No/ Çizim No: $7 / 2: 3$

Kaz. Env. No: AND15.GRN03.57

Tip: Tip 5

Buluntu Yeri/ Seviye: Horrea Hadriani/ Granarium Önü 3 Nolu Açma, $-188 \mathrm{~cm}$

Ölçüler: A.Ç.: $31 \mathrm{~cm}$, Kor. Y.: $10 \mathrm{~cm}$

Kil: 7.5 YR 4/6 (koyu kahverengi), seyrek dokulu, gözenekli, yoğun miktarda orta ve küçük boyutta taşç1k, siyah ince kum tanecikleri ve kireç katkılı kil. Astar: Yok.

Tanım: Kırık ve eksik durumda mortar ağız-gövde parçası.

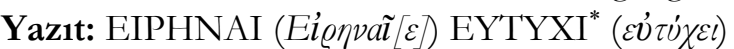

Yazıt Karşılaştırma: Hayes, 1967, s. 339, Fig. 2: 161; Vallerin, 1994, s. 176; Yangaki, 2009, s. 270-272; Çokay Kepçe, 2013, s. 166.

Karş1laştırma: Hayes, 1967, s. 340, Fig. 3: 2, 4; Riley, 1975, s. 41-42, no.66; Riley, 1979, Fig. 113: 679; Oren-Paskal, 2008, s. 36, Fig. 2: 13; Varga, 2010, s. 151-152, Fig. 4: 22, 5: 29; Vincenz, 2011, s. 191, Fig. 8.2: 11; Hortopan, 2011, Pl. I: 2, 4; Raičković, 2012, s. 151, Fig. 5: 33; Mills \& Reynolds, 2014, s. 140, Fig. 6: 24; Tahar vd., 2018, s. 176, Fig. 5: 52.

Tarih: MS 3-4. yüzy1l

Kat. No/ Çizim No: 8/ 2:4

Kaz. Env. No: AND15.GRND2.238

Tip: Tip 5

Buluntu Yeri/ Seviye: Horrea Hadriani/Granarium D2, $-238 \mathrm{~cm}$

Ölçüler: A.Ç.: $29.8 \mathrm{~cm}$ (iç), Kor. Y.: $6.6 \mathrm{~cm}$ 
Kil: 2.5 YR 4/4 (kırmızımsı kahverengi), seyrek dokulu, gözenekli, az miktarda küçük boyutta gümüş mika, yoğun miktarda büyük boyutta taşçık ve kireç katkılı kil. Astar: 2.5 YR 4/6 (kırmızı).

Tanım: Kırık ve eksik durumda mortar ağız-gövde parçası.

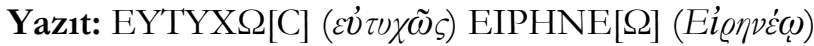

Yazıt Karşılaştırma: Hayes, 1967, s. 344; Riley, 1975, s. 43, Fig. 5; Groh, 1978, s. 167, 169, Pl. 1: 4; Yangaki, 2009, s. 268-270.

Karş1laştırma: Hayes, 1967, s. 340, Fig. 3: 2; Riley, 1975, s. 41-42, no.67; Groh, 1978, s. 167, 169, Pl. 1: 4; Tek, 2003, s. 403, Şek. 4; Oren-Paskal, 2008, s. 36, Fig. 2: 13; Vincenz, 2011, s. 191, Fig. 8.2: 11; Mills, 2014, s. 27, Fig. 10: 35; Mills \& Reynolds, 2014, s. 140, Fig. 6: 24; Gendelman, 2020, s. 168, Fig. 5: 9.

Tarih: MS 3-4. yüzyll

Kat. No/ Çizim No: 9/ 3:1

Tip: Tip 6

Buluntu Yeri/ Seviye: Horrea Hadriani/Granarium G2-A, -105/-125 cm

Ölçüler: A.Ç.: $38 \mathrm{~cm}$ (iç), Kor. Y.: $8.3 \mathrm{~cm}$

Kil: 2.5 YR 4/6 (kırmızı), seyrek dokulu, az gözenekli, az miktarda küçük boyutta şamot (grog) ve gümüş mika, yoğun miktarda orta ve küçük boyutta taşçı ve kireç katkılı kil. Astar: Yüzeydeki yoğun kireç patinasından dolayı görülememektedir.

Tanım: Kırık ve eksik durumda mortar ağız-gövde parçası.

Karşılaştırma: -

Tarih: MS 4-6. yüzyıl

Kat. No/ Çizim No: 10/ 3:2

Tip: Tip 6

Buluntu Yeri/ Seviye: Liman Yapıları Doğu Anıt Güneyi, +116 cm (Yüzey Akıntısı)

Ölçüler: A.Ç.: $32 \mathrm{~cm}$ (iç), Kor. Y.: $5.9 \mathrm{~cm}$

Kil: 2.5 YR 5/6 (kırmız1), sık dokulu, az gözenekli, yoğun miktarda küçük boyutta taşçk, az miktarda küçük boyutta şamot (grog), gümüş mika ve kireç katkılı kil. Astar: 2.5 YR 4/6 (kırmız1).

Tanım: Kırık ve eksik durumda mortar ağız-gövde parçası.

Karş1laştırma: Riley, 1975, s. 36-37, no. 42; Oren-Paskal, 2008, s. 36, Fig. 2: 15; Mills, 2014, s. 27, Fig. 10 :

M32.2 B1.2, M32.1 Ba1.13; Mills \& Reynolds, 2014, s. 141, Fig. 7: 30; Kereci, 2019, s. 169, Lev. 8: 85.

Tarih: MS 4-6. yüzyıl

Kat. No/ Çizim No: $11 / 3: 3$

Tip: Tip 6

Buluntu Yeri/ Seviye: 2015 İşlik Kazısı Atık Toprağ1

Ölçüler: A.Ç.: $44 \mathrm{~cm}$ (iç), Kor. Y.: $7.4 \mathrm{~cm}$

Kil: 2.5 YR 4/6 (kırmızı), sı1k dokulu, gözenekli, yoğun miktarda küçük boyutta taşç1k, gümüş mika ve kireç katkılı kil. Astar: 10 R 4/6 (kırmızı).

Tanım: Kırık ve eksik durumda mortar ağız-gövde parçası.

Karş1laştırma: Hayes, 1967, s. 340, Fig. 3: 6; Kereci, 2019, s. 168, Lev. 8: 84.

Tarih: MS 4-6. yüzy1l

Kat. No/ Çizim No: $12 / 3: 4$

Tip: Tip 6

Buluntu Yeri/ Seviye: 2015 İşlik Kazısı Atık Toprağ1

Ölçüler: A.C..: $36 \mathrm{~cm}$ (iç), Kor. Y.: $6.7 \mathrm{~cm}$

Kil: 2.5 YR 4/8 (kırmız1), seyrek dokulu, az gözenekli, çok yoğun miktarda büyük, orta ve küçük boyutta taşç1k, çok az miktarda küçük boyutta kuvars, az miktarda küçük boyutta gümüş mika, yoğun miktarda orta ve küçük boyutta kireç katkılı kil. Astar: Yok.

Tanım: Kırık ve eksik durumda mortar ağız-gövde parçası.

Karşılaştırma: Hayes, 1967, s. 340, Fig. 3: 5.

Tarih: MS 4-6. Yüzyıl 


\section{Extended Abstract}

Andriake is the port settlement of the ancient city of Myra in Demre District of Antalya Province. It is located in the Çayağz1 area, where Kokarçay (Andriakos) flows into the sea at the present time. Excavations in Andriake port have been carried out since 2009 by a large team led by Prof. Dr. Nevzat Çevik. These excavations were carried out in many buildings in the harbor such as Horrea Hadriani/Granarium, Agora/Plakoma, Germanicus Square, Harbor Buildings, Synagogue, Wine Workshops, Eastern and Western Baths, Church A and B, Honorific Monuments and Southeast Necropolis. As a result of the excavations, it is understood that Andriake port was inhabited continuously from the end of the 4th century BC to the middle of the 7 th century AD.

In this study, 12 terracotta mortars unearthed in the excavations in the Wine Workshops, Workshop Excavation Soil in 2015, Horrea Hadriani/Granarium, Synagogue, Front of Horrea Hadriani/Granarium, and Harbor Buildings were analyzed (Photograph 1,2). Mortars, known by different names in different

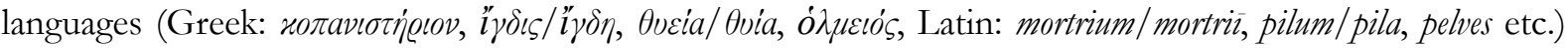
are among the indispensable containers of the kitchens in the archaic period. Mortars, whose history goes back to the Paleolithic Period, acquired their conventional form at the end of the 8th century BC. Terracotta and stone mortars found in a wide geographical area (Phoenicia, the Levant, Aegean region, Eastern Mediterranean region, Cyprus, Egypt, Northern Syria, Southern Anatolian coasts, Pannonia, Britain, Germany and Gaul, etc.) have been in use since the end of the 8th century BC. It has been used in many different areas such as making bread, cake, porridge, puree, soup and cheese, marinating meats, crushing various grains, herbs and spices in the kitchen. Outside the kitchen, they have been used in many different areas, in sacred ceremonies, measurement of dry foods, medicine and cosmetics, crushing glass and certain metals, making paint, as urns in burial rituals, as grave gifts, as pithos and amphora covers.

Roman terracotta mortars unearthed at Andriake were analyzed in six different types according to their mouth profiles. There are two specimens of Type 1 mortars (Cat. No: 1-2, Illustration 1: 1-2). This type, dated between the end of the 1 st century $\mathrm{BC}$ and the 2 nd century $\mathrm{AD}$, is known in the literature as Italian mortar. Close similars of Andriake Type 1 are found in Berenice, South Yorkshire, Albintimilium, Rome, Ilok, Via Sacchi, Alpes-Maritimes, Segobriga, Nepi, Cremona, Drôme, Salla and Nauportus. Only one Type 2 mortar specimen was found (Cat. No: 3, Illustration 1: 3). No similars were found for this type, dated between 2-4 AD. The clay of Andriake Type 2 mortar, which has high density, low porosity and is mixed with lime, grit and chamotte, is similar to the contents of the clay of Myra-Andriake ceramics. Therefore, it is believed that type 2 mortar is a local type manufactured in Myra. The only specimen of Andriake Type 3 is dated to the 5th century AD (Cat. No: 4, Illustration 1: 4). Although its close similar was found in Ras el Bassit (Syria), currently it is not clear where this type might have been manufactured. There is also one specimen of Andriake Type 4 mortars, known as Italian mortars (Cat. No: 5, Illustration 2: 1). Close similars of the Type 4 mortar dated between the end of the 1 st century AD and the 3rd century AD, were found in Aquincum, Vieux-Lyon, Salla, and Ilişua. There are three Type 5 mortars in Andriake (Cat. No: 6-8, Illustration 2: 2-4). There are two lines of inscriptions in Greek on the rim of two of these specimens (Cat. No:7,8). The inscription EIPHNAI EYTYXI* (Ei of the mouth of the mortar with the catalog no 7, is a good luck wish, meaning "Ob! Eirenaios, be successful"

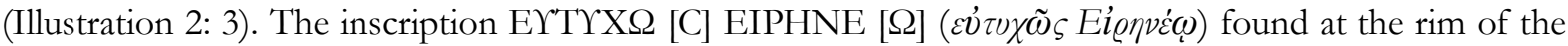
mouth of the mortar with the catalog no 8 is translated as "Eutykhos son of Eireneos" (Illustration 2: 4). This inscription must be indicating the name of the manufacturer/workshop that manufactured the mortar or the person who gifted it. Type 5 mortars are dated to the 3rd-4th century AD. Their similars have been found in Caesarea, Salla, Viminacium, Shuni, Lagoz, Temple Mount (Israel), Dacia, Ras el Bassit, Yafo/Jaffa, Berenice, Bat Galim, Tunisia and Arykanda. Four of the Andriake Type 6 mortars were unearthed (Cat. No: 9-12, Illustration 3: 1-4). The similars of this type, which is dated to the 4th-6th century AD, can be found in the Ancient Agora of Athens, Abu Mena, Caesarea, Bat Galim, Ras el Bassit and Hatay. Andriake Type 5 and Type 6 mortars are known as Syrian mortars in the literature. However, the clay content of these two types differs from their similars. So, whether Type 5 and Type 6 specimens were manufactured in Syria or in Myra will be clarified by petrographic analyses that will be carried out in the following years. 
When Roman mortars from Andriake are analyzed, it is seen that the ancient city of Myra established commercial relations with Italy and Syria through its port. As a result of this study, new types were added to the provincial and regional mortar typology and contribution was made to the ceramic works of the region.

Keywords: Myra (Lycia), Andriake Port, Roman Period, Mortaria/Mortarium, grinding bowl

\section{Kaynakça}

\section{Antik Kaynaklar}

Oribasius, Collectiones medicae: Oribasii collectionum medicarum reliquiae, Vol. I-IV, (Ed. I. Raeder), Lipsiae-Berolini, 1928-1933.

\section{Modern Kaynaklar}

Akyürek, T. E. (2014). Andriake. Geç Antik Çağ'da Myra'nın Limanı. Toplumsal Tarih, 246, 52-57.

Amit, D., \& Adler, Y. (2018). The Stone Vessels, Içinde O. Tsuf, Ancient Jaffa from the Persian to the Byzantine Period Kaplan Excavations (1955-1981) (ss. 538-572), The Jaffa Cultural Heritage Project Series Vol. 3, Münster: Zaphon.

Aygün, C.. A. (2012). Andriake Mureks Boya Endüstrisi. Yayınlanmamış yüksek lisans tezi, Akdeniz Üniversitesi Sosyal Bilimler Enstitüsü Arkeoloji Anabilim Dalı, Antalya.

Aygün, Ç. A. (2018). Myra’nnn Liman Andriake'nin Yerlessim Plan. Yayınlanmamış doktora tezi, Akdeniz Üniversitesi Sosyal Bilimler Enstitüsü Arkeoloji Anabilim Dalı, Antalya.

Bellelli, V., \& Botto, M. (2002). I bacini di tipo fenicio-cipriota: considerazioni sulla diffusione di una forma ceramica nell'italia medio-tirrenica nel periodo compreso fra il VII e il VI secolo a.C. In O. Paolette, L. T. Perna (Eds.), Etruria e Sardegna centro-settentrionale tra l'età del bronzo finale e l'arcaismo. Atti del XXI Convegno di studi etruschi ed italici, Sassari, Alghero, Oristano, Torralba, 13-17 ottobre 1998 (ss. 277-307), Pisa.

Berden, T., Čufar, K., \& Horvat, J. (2019). Selected Early Imperial Contexts from Nauportus: Breg Area. In H. Dolenz, K. Strobel (Eds.), Chronologie und vergleichende Chronologien zum Ausgang der Römischen Republik und zur Früben Kaiserzeit: Tagungsband des internationalen Kolloquiums anlässlich 70 Jabre Archäologische Ausgrabungen auf dem Magdalensberg: zugleich Festgabe für Eleni Schindler Kaudelka (ss. 35-62), Kärnten: Landesmuseums für Kärnten.

Buckland, P. C., Magilton, J. R., \& Dolby, M. J. (1980). The Roman Pottery Industries of South Yorkshire: A Review. Britannia, 11, 145-164.

Bulut, S., \& Şengül, M. (2010). 2009-2010 Yılı Andriake Kazılarında Bulunan Sikkeler Hakkında Ön Rapor. İçinde N. Çevik (Ed.), Arkeolojisinden Doğasina Myra/Demre ve Cevresi (ss. 119-125), Antalya: T.C. Kültür ve Turizm Bakanlı̆g1 Yayınları.

Bulut, S., \& Şengül, M. (2014). 2009-2012 Y1lları Andriake Kazı Sikkeleri ve Yerleşim Tarihine Katkıları. İçinde K. Dörtlük, O. Tekin, R. Boyraz Seyhan (Eds.), Birinci Uluslararası Anadolu Para Taribi ve Numismatik Kongresi - Bildiriler (ss. 79-110), Antalya: AKMED.

Cramp, L. J. E., Evershed, R. P., \& Eckardt, H. (2011). What was a mortarium used for? Organic residues and cultural change in Iron Age and Roman Britain. Antiquity, 85, 1339-1352.

Crawford, J. S. (1990). The Byzantine Shops at Sardis, London: Harvard University Press.

Çevik, N. (2010a). Myra ve Limanı Andriake. Kazılar Başlarken Ön-Düşünceler. Arkeoloji ve Sanat Dergisi, 134, 53-82.

Çevik, N. (2010b). Myra ve Andriake Kazıları'nda Illk Yıl: 2009/ The First Season of Excavations in Myra and Andriake: 2009. ANMED, 8, 55-60.

Çevik, N. (2016). Mür Soluyan Kent: Myra. İçinde H. İşkan, E. Dündar (Eds.), Lukka'dan Likya'ya. Sarpedon ve Aziz Nikolaos'un Ülkesi (ss. 224-237), İstanbul: Yap1 Kredi Yayınlar1.

Çevik, N., \& Bulut, S. (2010). İkinci Kazı Sezonunda Myra ve Limanı Andriake. İçinde N. Çevik (Ed.), Arkeolojisinden Doğasina Myra/Demre ve Cevresi (ss. 25-118), Antalya: T.C. Kültür ve Turizm Bakanliğ1 Yayınları.

Çevik, N., \& Bulut, S. (2011). Myra ve Andriake Kazllar1 2010/ Excavations at Myra and Andriake in 2010. ANMED, 9, 59-70. 
Çevik, N., \& Bulut, S. (2014). Andriake Doğu Hamamı: Bölgenin Hamam Mimarllğına Işık Tutan Yeni Bir Örnek. Adalya, 17, 221-263.

Çevik, N., \& Eshel, H. (2010). A Byzantine Synagogue in Andriake in Southern Turkey. Qadmoniot, 43, 41-43.

Çevik, N., Çömezoğlu, Ö., Öztürk, H. S., \& Türkoğlu, İ. (2010a). A Unique Discovery in Lycia: The Ancient Synagogue at Andriake, Port of Myra. Adalya, 13, 335-366.

Çevik, N., Çömezoğlu, Ö., Öztürk, H. S., \& Türkoğlu, İ. (2010b). Andriake Sinagogu ve Bölgede Yahudi Varlı̆̆ı. İçinde N. Çevik (Ed.), Arkeolojisinden Doğasına Myra/Demre ve Cevresi (ss. 169-180), Antalya: T.C. Kültür ve Turizm Bakanlığı Yayınları.

Çevik, N., Bulut, S., T1bıkoğlu, O., Özdilek, B., \& Aygün, Ç. A. (2011). Myra ve Andriake Kazılanında İlk Yıl: 2009. Kaそ̨ Sonuçar Toplantısı, 32(1), 403-420.

Çevik, N., Bulut, S., \& Akyürek, T. E. (2012). Myra-Andriake Kazıları ve Araştırmaları 2011/

Excavations and Surveys at Myra-Andriake in 2011. ANMED, 10, 65-72.

Çevik, N., Bulut, S., \& Akyürek, T. E. (2013). Myra ve Andriake Kazıları 2012/ Excavations at Myra and Andriake 2012. ANMED, 11, 90-96.

Çevik, N., Bulut, S., \& Aygün, C.. A. (2014). Myra’nın Limanı Andriake. İçinde S. Ladstatter, F. Pirson, T. Schmidts (Eds.), Harbors and Harbor Cities in the Eastern Mediterranean, BYZAS, 19(1), 225-244.

Çevik, N., Bulut, S., Aygün, Ç. A., \& Çömezoğlu Uzbek, Ö. (2017). 2016 Yll Myra ve Andriake Kaz1lar1/ Myra and Andriake Excavations of 2016. ANMED, 15, 67-75.

Çevik, N., Bulut, S., Aygün, C.. A., Çömezoğlu Uzbek, Ö., Tiryaki Türkmenoğlu, H. A., \& PimouguetPédarros, I. (2018a). Myra-Andriake 2017. ANMED, 16, 75-81.

Çevik, N., Bulut, S., Aygün, Ç. A., \& Çömezoğlu Uzbek, Ö. (2018b). Myra-Andriake 2016. Kaž Sonuclar Toplantısi, 39(2), 189-204.

Çokay Kepçe, S. (2013). Pamphylia Bölgesi’nden 'Kuzey Suriye' Mortariumları. İçinde O. Tekin, M. H. Sayar, E. Konyar (Eds.), Tarban Armağan M. Taner Tarhan'a Sunulan Makaleler (ss. 165-173), İstanbul: Ege Yayinları.

Çokay Kepçe, S. (2017). Perge Batı Nekropolis Mez̧ar Buluntular. 1997-2007 Yillarn Arasında 169 Numaralı Parselde Yürütülen Callsmalar. İstanbul: Ege Yayınları.

Demir, E. C.. (1999). Antik Că̆da Cam ve Perge Konut Alanı 'A Evi' Cam Eserleri. Yayınlanmamış yüksek lisans tezi, İstanbul Üniversitesi Sosyal Bilimler Enstitüsü Arkeoloji Anabilim Dalı, İstanbul.

Demir, S. (2015). Türkiye'de Yetissen Yerel Emmer Buğday (Triticum turgidum L. ssp. dicoccon (Schrank) Thell.) Popülasyonlarnda Genetike Cesittlilï̌in Moleküler Yöntemlerle Karakterizasyonu. Yayınlanmamış yüksek lisans tezi, Hitit Üniversitesi Fen Bilimleri Enstitüsü Biyoloji Anabilim Dalı, Çorum.

Doğan, S. (2007). Bizans Döneminde Pamfilya ve Likya'da Gündelik Kullanımdaki Taş Gereçler. Hacettepe Üniversitesi Edebiyat Fakültesi Dergisi, 24(2), 63-75.

Fernándes, R. C., \& Uceda, I. H. (2011). Los Morteros Centroitálicos de Segobriga. Lvcentvm, 30, 127142.

Gaiu, C. (2016-2017). Mortaria din castrul roman de la Ilişua. Revista Bistriței, 30-31, 76-97.

Gendelman, P. (2020). Pottery Vessels and Stone Artifacts from the Persian, Roman and Byzantine Periods at the French Hospital Compound, Yafo (Jaffa). Atiqot, 100, 157-188.

Gilles, A. (2013). La production et la consommation des céramiques dans la région de Valence

(Drôme) au IIIe s. In S. Mauné, G. Duperron, Du Rhône aux Pyrénées: aspect de la vie matérielle en Gaule Narbonnaise II. Archéologie et Histoire Romaine 25 (ss. 169-200), Montagnac.

Greene, E. S., Lawall, M. L., \& Polzer, M. E. (2008). Inconspicuous Consumption: The Sixth-Cnetury

B.C.E. Shipwreck at Pabuç Burnu, Turkey. American Journal Archaeology, 112(4), 685-711.

Greene, E. S., Leidwanger, J., \& Özdaş, H. (2013). Expanding Contact and Collapsing Distances in Early Cypro-Archaic Trade: Three Case Studies of Shipwrecks of the Turkish Coast. In M. L. Lawall, J. Lund (Eds.), The Transport Amphorae and Trade of Cyprus (ss. 22-34), England: Aarhus University Press.

Groh, D. E. (1978). 4: North Syrian Mortaria Excavated at Caesarea Maritima (Israel). Levant, 10(1), 165-169. 
Hayes, J. W. (1967). North Syrian Mortaria. Hesperia, 36(4), 337-347.

Hortopan, D. (2011). Recipiente de tip mortaria descoperite în Dacia meridionelă în secolele II-III p. Chr. LITUA studii si cercetari, 13, 63-67.

Jacopi, G. (1931). Clara Rhodos IV, Esplorazione archeologica di Camiro I: scavi nelle necropoli Camiresi 19291930, Rodi: Istituto storico-archeologico.

Jagusiak, K., Kokoszko, M., \& Rzeźnicka, Z. (2015). Cakes and Breads in Oribasius Collectiones Medicae. Symbolae Philologorum Posnaniensium Graecae et Latinae, 25(1), 127-140.

Jelinčić, K. (2003). Rimska keramika iz Iloka/Roman Pottery from Ilok. Prilozi Instituta za arheologiju u Zagrebu, 20, 79-88.

Karageorghis, V. (1967). Excavations in the Necropolis of Salamis I. Nicosia: Cambridge University Press.

Karageorghis, V. (1970). Excavations in the Necropolis of Salamis II. Nicosia: Cambridge University Press.

Karageorghis, V. (1973). Excavations in the Necropolis of Salamis III. Nicosia: Cambridge University Press.

Karageorghis, V. (1978). Excavations in the Necropolis of Salamis IV. Nicosia: Cambridge University Press.

Karivieri, A. (1996). The Athenian Lamp Industry in Late Antiquity. Papers and Monographs of the Finnish Institute at Athens $V$, Helsinki.

Kereci, M. (2019). Hayat İli Kuseyr Yaylası Kırsal Yerleşimleri Seramikleri. Yayınlanmamış yüksek lisans tezi, Hatay Mustafa Kemal Üniversitesi Sosyal Bilimler Enstitüsü Arkeoloji Anabilim Dalı, Hatay.

Kokoszko, M., Jagusiak, K., \& Dybala, J. (2016). Bread as Food and Medicament in Oribasius' Writings. Studia Ceranea, 6, 355-376.

Korkut, T. (2002). Steinerne Mörserschalen aus Patara. Archäologischer An₹eiger, 1, 233-245.

Krekovič, E. (2016). Mortaria in Graves. Rei Cretarice Romance Favtorvm Acta, 44, 513-518.

Lehmann, G. (1996). Untersucbungen zur späten Eisenzeit Syrien und Libanon. Stratigrapbie und Keramikformen zwischen ca. 720 bis 300 v.Chr. Altertumskunde des Vorderen Orients 5, Münster: Ugarit.

Lehmann, G. (1998). Trends in the Local Pottery Development of the Late Iron Age and Persian Period in Syria and Lebanon, ca. 700 to 300 B. C. Bulletin of the American Schools of Oriental Research, 311, 737.

Marksteiner, T. (2006). Andriake Yüzey Araştırması 2005 Yılı Çalışmaları. Anmed, 4, 41-46.

Marksteiner, T. (2007). Andriake Yüzey Araştırması 2006. Anmed, 5, 98-101.

Matteucci, P. (1987). L’uso Dei Mortai Di Terracotta Nell'alimentazione Antica. Studi Classici e Orientali, $36,239-277$.

Megaw, A. H. S. (2007). Kourion. Excavations in the Episcopal Precinct, USA: Harvard University Press.

Mills, P., \& Rajala, U. (2011). The Roman Ceramic Material From Field Walking In The Environs of Nepi. Papers of the British School at Rome, 79, 147-240, 389-395.

Mills, P. J. E., \& Reynolds, P. (2014). Amphorae and Specialized Coarsewares of Ras al Bassit, Syria: Local Products and Exports. In N. Poulou-Papadimitriou, E. Nodarou, V. Kilikoglou (Eds.), LRCW 4 Late Roman Coarse Wares, Cooking Wares and Amphorae in the Mediterranean: Archaeology and archaeometry. The Mediterranean: a market without frontiers, BAR International Ser. 2616(1) (ss. 133-142), England.

Mills, P. (2014). The local pottery from Ras el Bassit. In B. Fischer-Genz, Y. Gerber, H. Hamel (Eds.), Roman Pottery in the Near East. Local Production and Regional Trade Proceedings of the Round Table Held in Berlin, 19-20 February 2010 (ss. 21-36), England.

Moritz, L. A. (1958). Grain-Mills and Flour in Classical Antiquity. London: Clarendon Press.

Olcese, G. (1993). Le Ceramiche Comuni Di Albintimilium Indagine Archeologica E Archeometrica Sui Materiali Dell'area Del Cardini. Firenze: Edizioni All'insegna del Giglio.

Olcese, G. (2003). Ceramiche comuni a Roma en in area romana: produzione, circolazione e tecnologia (tarda età repubblicana-prima età imperiale). Mantova: SAP.

Oren, E. D. (1984). Migdol: A New Fortress on the Edge of the Eastern Nile Delta. Bulletin of the American Schools of Oriental Research, 256, 7-44.

Oren-Paskal, M. (2008). Excavation at Bat Galim: The Pottery. Contract Archaeology Reports, 3, 32-53.

Özdemir, B. Ş. (2009). Patara Roma Dönemi Günlük Kullanım Seramikleri. Yayınlanmamış yüksek lisans tezi, Akdeniz Üniversitesi Sosyal Bilimler Enstitüsü Arkeoloji Anabilim Dalı, Antalya. 
Özdilek, B. (2015). Andriake Sinagogu'ndan Seçilmiş Örneklerle Hellenistik ve Roma Dönemi Seramiklerine Genel Bir Bakış. Cedrus, 3, 89-117.

Özdilek, B. (2016). 2009-2012 Andriake Kazılarından Ele Geçen Unguentarium, Şişe, Lykion ve Mortar Örnekleri. Olba, 24, 217-265.

Özdilek, B. (2017). Andriake Limanından Ele Geçen Doğu Sigillata C Grubu Pergamon-Çandarlı Sigillatalar1. Mustafa Kemal Üniversitesi Sosyal Bilimler Enstitïsü Dergisi, 14(40), 260-276.

Özdilek, B. (2018). Andriake Limanından Ele Geçen DSD Grubu/Kıbrıs Sigillataları Işığında Lykia’nın Doğu Akdeniz ile Deniz Ticareti. Phaselis, 4, 57-77.

Özer, B. (2017). Pedasa Athena Kutsal Alanı Arkaik Dönem Kıbrıs Mortarları ve Bölgeler Arası Ticari İlișkilerdeki Rölü. Adalya, 20, 41-67.

Öz, C. (2020). Myra ve Andriake Geş Roma Dönemi Seramikleri. Yayınlanmamış doktora tezi, Akdeniz Üniversitesi Sosyal Bilimler Enstitüsü Arkeoloji Anabilim Dalı, Antalya.

Pellegrino, E. (2009). La céramique commune d'époque romaine dans le département des AlpesMaritimes (II siécle av. J. C. au III e ap. J. C.). In Lés Céramiques Communes D'italie et de Narbonnaise. Structures de Production, Typologies et Contextes Inédits II siécle av. J. C. - III siécle ap. J. C. Collection du Centre Jean Bérard 30, 165-189.

Ragazzi, L., \& Frontori, I. (2018). Ceramica Comune Da Mensa, Da Dispensa E Di Uso Vario. In L. Arslan Pitcher (Ed.), Amoenissimis...Aedificiis. Gli Scavi Di Piazza Marconi A Cremona, Vol. II-I (ss. 29-88), Lombardia.

Ramos, A. C., Laço, T., Almeida, R., \& Viegas, C. (2007). Les Céramiques Communes Du VIe S. Du Complexe Industriel De Salaisons De Poisson De Lagos (Portugal). In M. Bonifay, J-C. Tréglia (Eds.), LRCW 2 Late Roman Coarse Wares, Cooking Wares and Amphorae in the Mediterranean: Archaeology and archaeometry, BAR International Ser. 1662 (I) (ss. 85-97), England.

Raičković, A. (2012). Late Roman Pottery from Viminacium-Thermae. The excavation of 2004. Rei Cretaria Romane Favtorvm Acta, 42, 147-154.

Riley, J. A. (1975). The Pottery from the First Session of Excavation in the Caesarea Hippodrome. BASOR, 218, 25-63.

Riley, J. A. (1979). The Coarse Pottery from Berenice. In J. A. Lloyd (Ed.), Excavations at Sidi Khrebish Benghari (Berenice) 2, Libya Antiqua Suppl. V (ss. 91-467), Tripoli.

Quercia, A. (2008). Le ceramiche comuni di éta romana. In Filippi, F. (Ed.), Horti er Sordes. Uno scavo alle falde del Gianicolo (ss.141-176), Roma: Quasar.

Sapin, J. (1998). Mortaria: Un lot inedit de Tell Keisan. Essai d'interpretation fonctionnelle. Transeuphratène, 16, 87-120.

Symonds, R. P. (2012). A brief history of the ceramic mortarium in antiquity. Journal of Roman Pottery Studies, 15, 169-214.

Tahar, S. B., Bonifay, M., \& Capelli, C. (2018). L’atelier céramique d’Oued el Akarit (Tunisie). Antiquités africaines, 54, 169-180.

Tek, A. T. (2003). Geç Roma İmparatorluk Çağında Üretilmiş Grekçe Damgalı Pişmiş Toprak Mortariumlar. III. Uluslararası Eskişehir Pişmiş Toprake Semposynmu 16-30 Hą̧iran 2003 Eskişehir, Bildiriler Kitabı (ss. 395-403), Eskişehir.

Thompson, H. A. (1934). Two Centuries of Hellenistic Pottery. Hesperia, 3(4), 311-476.

Tombul, M. (2006). Troas Bölgesi Hellenistik ve Roma Dönemi Taş Kapları. İçinde T. Takaoğlu (Ed.), Anadolu Arkeolojisine Katkelar 65. Yasinda Abdullab Yaylali'ya Sunulan Yąllar (ss. 254-262), İstanbul.

Türkmen, B. (2009). Allionai'de Bulunan Equme ve Öğ̈̈tme Taş Aletleri ile Taş Kaplar. Yayınlanmamış yüksek lisans tezi, Trakya Üniversitesi Sosyal Bilimler Enstitüsü Arkeoloji Anabilim Dalı, Edirne.

Varga, G. (2010). Roman Mortaria From Salla. Acta Archaeologica Academiae Scientiarum Hungaricae, 61, 145-184.

Vallerin, M. (1994). Pelves Estampillés de Bassit. Syria, 71(1-2), 171-204.

Vallet, C. B., \& Lemaître, S. (2008). Le mobilier céramique d'un site antique du Vieux-Lyon fréquenté entre le deuxiéme quart du Ier s. av. J.-C. et le début du Ve s. ap. J.-C.: le Museé Gadagne. Revue archéologique de Narbonnaise, 41, 211-260. 
Vincenz, A. de (1998). Two Stamped Syrian Mortaria from Shuni. Bulletin of the Anglo-Israel Archaeological Society, 16, 71-74.

Vincenz, A. de (2011). The Pottery Assemblage from the Bakery. In E. Mazar, The Temple Mount Excavations in Jerusalem 1968-1978 Directed by Benjamin Mazar: Final Report IV: The Tenth Legion in Aelia Capitolina (ss. 185-194), Qedem 52, Israil: Hebrew University of Jerusalem.

Villing, A. (2006). Drab Bowls' for Apollo: The Mortaria of Naukratis and Exchange in the Archaic Eastern Mediterranean. In A. Villing, U. Schlotzhauer (Eds.), Naukratis: Greek Diversity in Egypt. Studies on East Greek Pottery and Exchange in the Eastern Mediterranean (ss. 31-46), London: The British Museum Press.

Villing, A. (2009). The Daily Grind of Ancient Greece: Mortars and Mortaria between Symbol and Reality. In A. Tsingarida (Ed.), Shapes and Uses of Greek V ases (7th -4th centuries B.C.). Proceedings of Symposium beld at the Université de Bruxelles 27-29 April 2006, Études d'Archéologie 3 (ss. 319-333), Brussels.

Villing, A., \& Pemberton, E. G. (2010). Mortaria from Ancient Corinth: Form and Function. Hesperia, 79(4), 555-638.

Waldbaum, J. C., \& Magness, J. (1987). The Chronology of Early Greek Pottery: New Evidence from Seventh-Century B. C. Destruction Level in Israel. American Journal of Archaeology, 101(1), 23-40.

Yangaki, A. G. (2009). North Syrian Mortaria and Other Late Roman Personel and Utility Objects Bearing Inscriptions of Good Luck. Byzantina Symmeikta, 19, 247-287.

Yener-Marksteiner, B. (2009). Andriake Yüzey Araştırması 2008. Anmed, 7, 105-107

Yener-Marksteiner, B. (2013). Vorläufige Ergebnisse der Untersuchungen der Keramikfunde des Andriake-Surveys. İçinde P. Brun, L. Cavalier, K. Konuk, F. Prost (Eds.), Euploia. La Lycie et la Carie Antiques. Actes du colloque de Bordeaux 5, 6, 7 novembre 2009 (ss. 225-232), Ausonius Mémoires, 34, Bordeaux.

Yıldızlı, M., \& Ergürer, H. E. (2019). Parion Roma Dönemi Taş Kapları (2010-2018). İçinde V. Keleş, H. Kasapoğlu, H. E. Ergürer, E. Çelikbaş, A. Yılmaz (Eds.), Cevat BAŞARAN'a 60. Yaş Armağan (ss. 625656), Ankara: Bilgin Kültür Sanat.

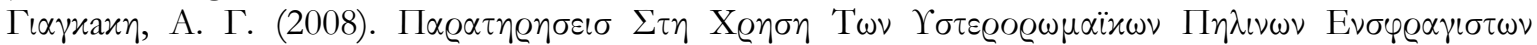

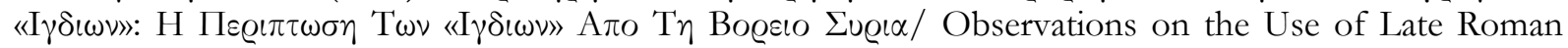
Impressed Clay Mortars: The Case of 'North-Syrian Mortaria. Byzantina Symmmeikta, 18, 35-75.

Zsidi, P., \& Balla, M. (2000). The Distribution of Mortars From The So-Called Gas-Works Pottery' Workshop In Aquincum. Rei Cretaria Romance Favtorvm Acta, 36, 247-253.

Zukerman, A., \& Ben-Shlomo, D. (2011). Mortaria as a Foreign Element in the Material Culture of the Southern Levant during the $8^{\text {th }} 7^{\text {th }}$ Centuries BCE. Palestine Exploration Quarterly, 143(2), 87-105. 
EKLER

GÖRSELLER

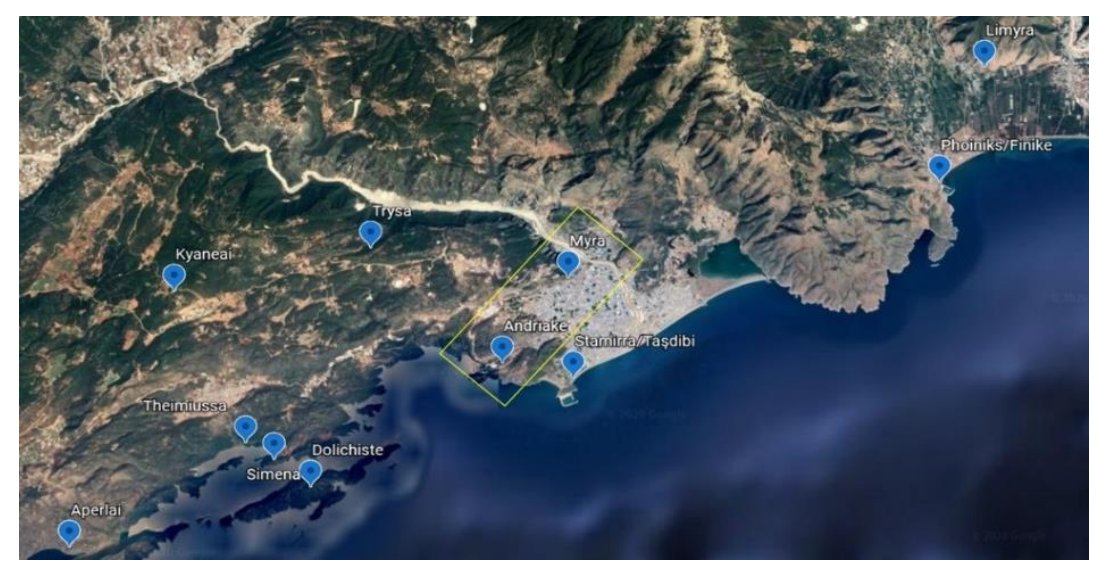

Harita 1: Myra ve Andriake'nin Konumu (C Google Earth’ten yararlanılarak oluşturulmuştur)

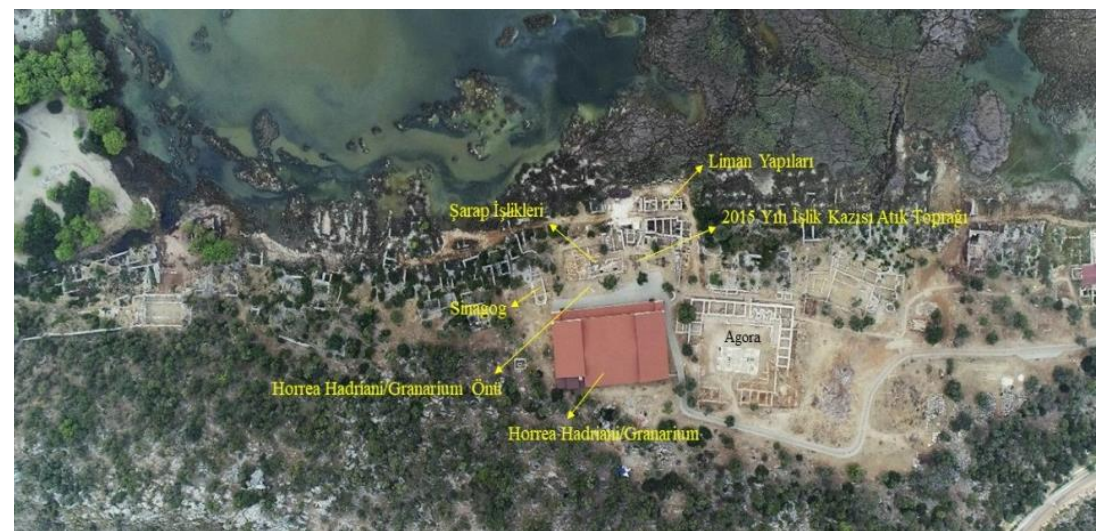

Fotoğraf 1: Andriake'de Mortarların Ele Geçtiği Alanlar (C Myra-Andriake Kazı Arşivi)

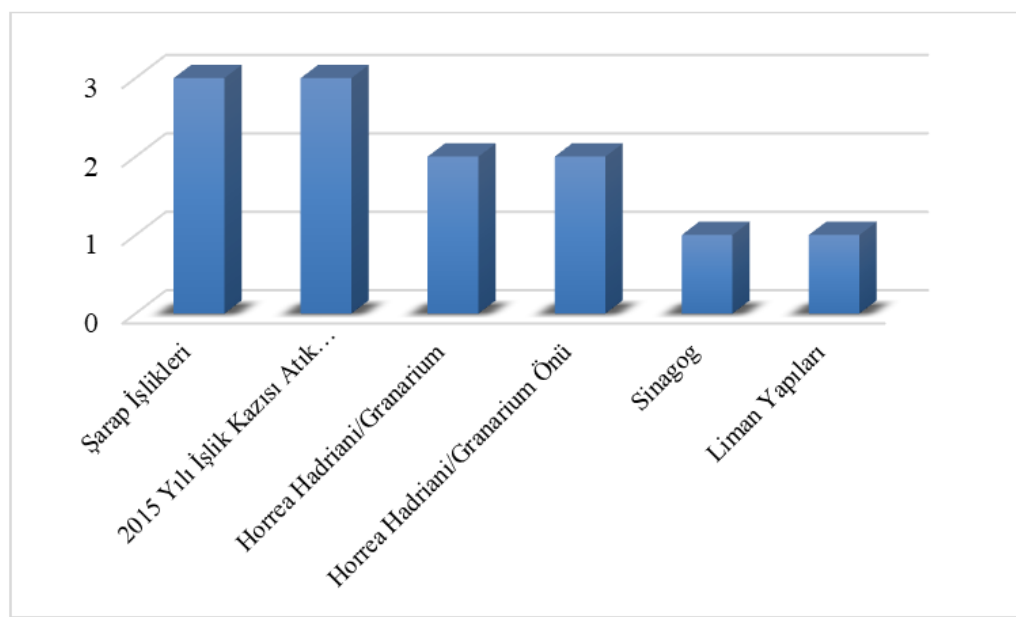

Fotoğraf 2: Mortarların Ele Geçtiği Alanlara Göre Dağılımını Gösterir Grafik 


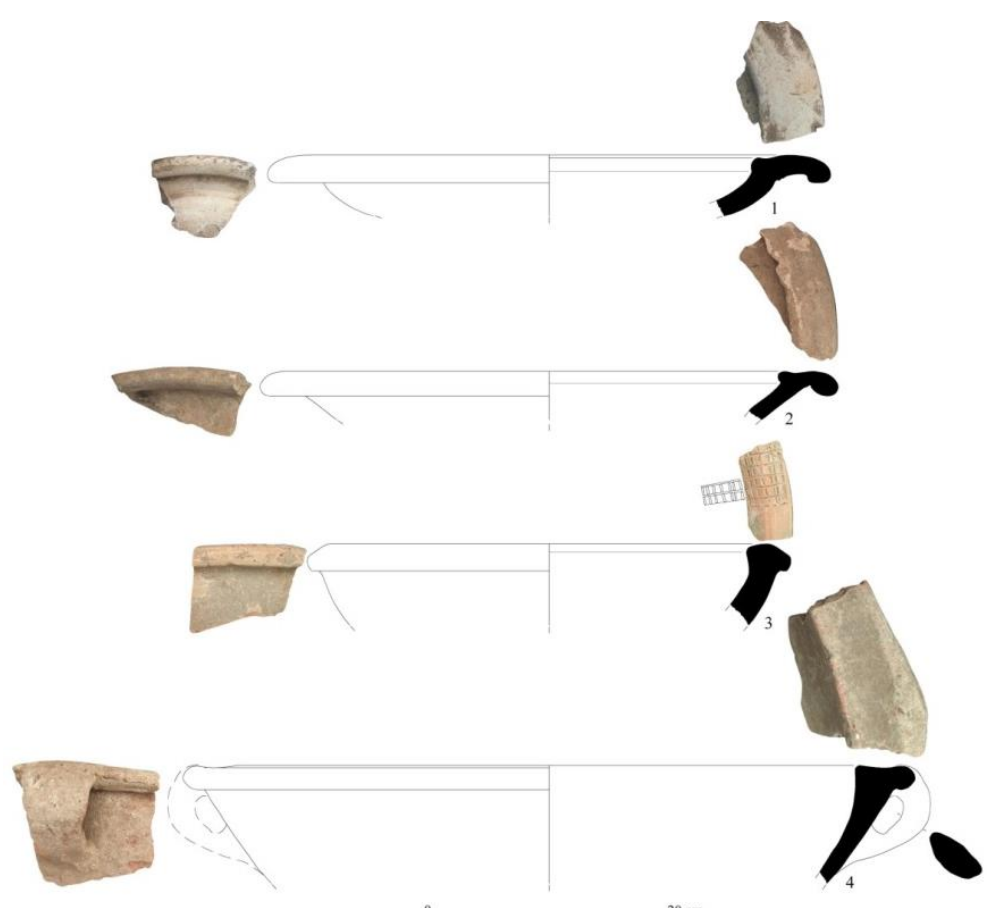

Çizim 1: 1-2: Tip 1, 3: Tip 2, 4: Tip 3 (C C. Öz)

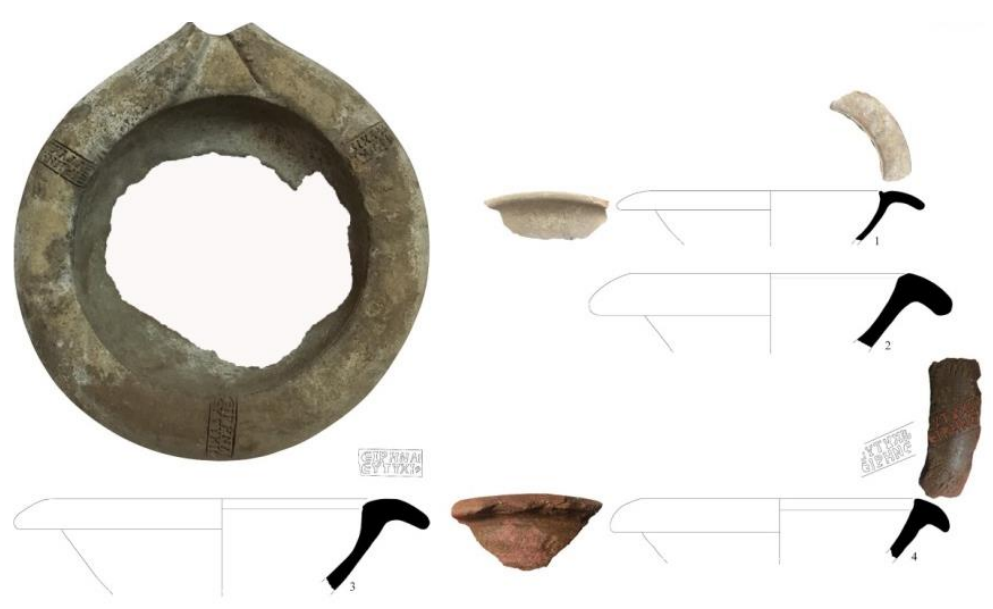

Çizim 2: 1: Tip 4, 2-4: Tip 5 (C C. Öz) 


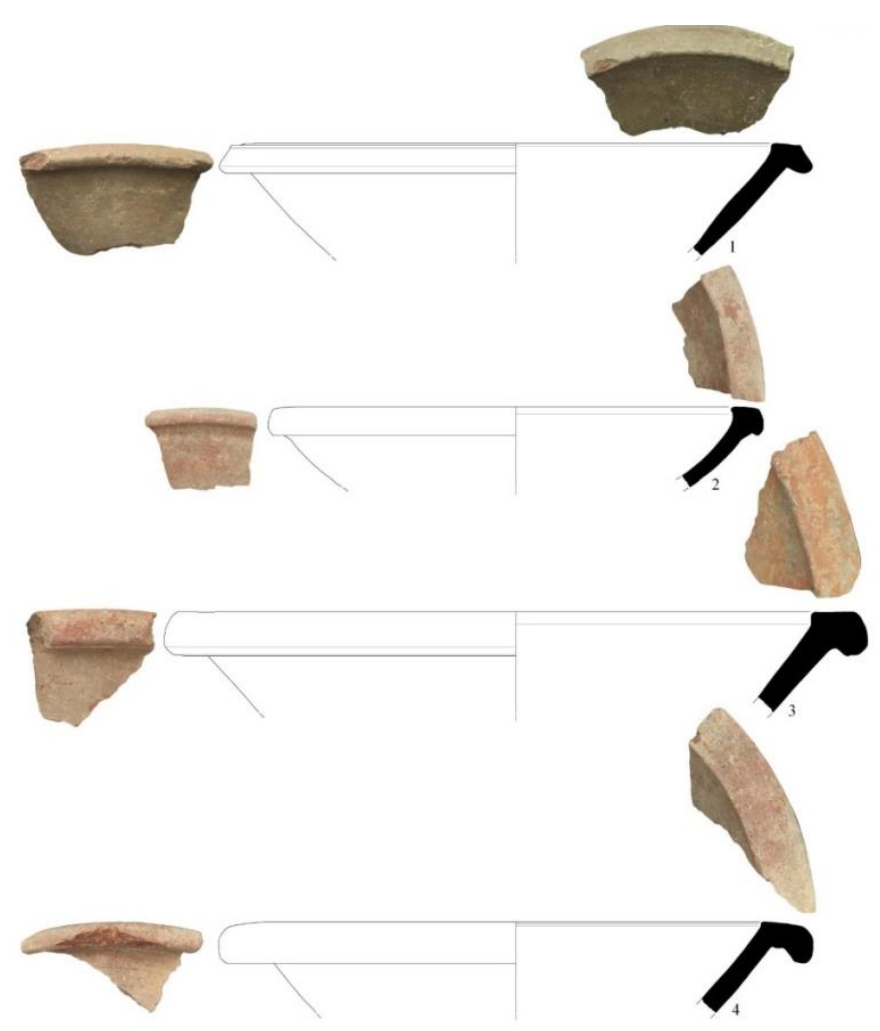

Çizim 3: 1-4: Tip 6 (С C. Öz) 